\title{
Titanium: An Overview of Resources and Production Methods
}

\author{
Mohammed El Khalloufi (D), Olivier Drevelle and Gervais Soucy *(D)
}

check for updates

Citation: El Khalloufi, M.; Drevelle,

O.; Soucy, G. Titanium: An Overview of Resources and Production Methods. Minerals 2021, 11, 1425. https://doi.org/10.3390/ $\min 11121425$

Academic Editors: Shuai Wang, Xingjie Wang and Jia Yang

Received: 15 November 2021 Accepted: 12 December 2021 Published: 16 December 2021

Publisher's Note: MDPI stays neutral with regard to jurisdictional claims in published maps and institutional affiliations.

Copyright: (c) 2021 by the authors. Licensee MDPI, Basel, Switzerland. This article is an open access article distributed under the terms and conditions of the Creative Commons Attribution (CC BY) license (https:// creativecommons.org/licenses/by/ $4.0 /)$.
Département de génie chimique et de génie biotechnologique, Université de Sherbrooke, Sherbrooke, QC J1K 2R1, Canada; Mohammed.El.Khalloufi@USherbrooke.ca (M.E.K.); Olivier.Drevelle@Usherbrooke.ca (O.D.)

* Correspondence: gervais.soucy@USherbrooke.ca; Tel.: +1-819-821-8000 (ext. 62167)

\begin{abstract}
For several decades, the metallurgical industry and the research community worldwide have been challenged to develop energy-efficient and low-cost titanium production processes. The expensive and energy-consuming Kroll process produces titanium metal commercially, which is highly matured and optimized. Titanium's strong affinity for oxygen implies that conventional Ti metal production processes are energy-intensive. Over the past several decades, research and development have been focusing on new processes to replace the Kroll process. Two fundamental groups are categorized for these methods: thermochemical and electrochemical. This literature review gives an insight into the titanium industry, including the titanium resources and processes of production. It focuses on ilmenite as a major source of titanium and some effective methods for producing titanium through extractive metallurgy processes and presents a critical view of the opportunities and challenges.
\end{abstract}

Keywords: titanium; titanium alloys; ilmenite; extractive metallurgy; $\mathrm{TiO}_{2}$; calciothermic reduction

\section{Introduction}

Titanium is a transition metal that is used more in the production of high-strength, corrosion-resistant, and thermally stable metal alloys for the aerospace and shielding industries. The titanium production cost has so far hindered the growth in the use of this metal relative to other base metals on the market, even though titanium is the fourth most abundant structural metal in the earth's crust with $0.6 \%$. It comes after iron, magnesium, and aluminum, but remains exotic due to its prohibitive cost [1,2], which prevents the metal from reaching its full potential in marine and automotive industry applications. Older production technology, high energy losses, and loss of material or metal are some of the problems associated with the production of titanium metal [3]. Further, all base metals are inferior to titanium in terms of specific mechanical and chemical properties, but titanium has not yet been fully exploited $[1,2,4]$. Titanium exhibits unique properties, some of which are proprietary, which could help it replace common metals and alloys such as steel and aluminum in many applications [5].

The current commercial method of titanium production is the Kroll process, marketed by DuPont Germany in 1948 [4]. It is a discontinuous, energy-, and labor-intensive process whose strict conditions make it expensive; therefore, researchers around the world are investigating new methods for extracting titanium from its precursors. Titanium is mainly produced from minerals such as ilmenite $\mathrm{FeTiO}_{3}$ and rutile $\left(\mathrm{TiO}_{2}\right)$ while smaller quantities are produced from perovskite $\left(\mathrm{CaTiO}_{3}\right)$ and titanite or sphene $\left(\mathrm{CaTiSiO}_{5}\right)$ [6]. The main ilmenite deposits are located in Australia, China, Norway, Canada, Madagascar, India, South Africa, and Vietnam, while rutile deposits are found in Sierra Leone, the United States, India, and South Africa [7].

Ilmenite is a significant mineral [8], which contains between $40 \%$ and $65 \%$ titanium dioxide. The other elements are either ferrous oxide or ferric oxide and sometimes small amounts of vanadium, magnesium, and/or manganese. Ilmenite's main sources are the 
heavy mineral sands (alluvial deposits) but are also commonly distributed in hard rock [9]. Currently, ilmenite accounts for $92 \%$ of the world's titanium mineral production. Rutile $\left(\mathrm{TiO}_{2}\right)$ has a titanium dioxide content of $93-96 \%$ but is difficult to find in natural ilmenite deposits [7]. Thereby, the present review focuses on the alluvial deposit, more precisely the ilmenite, and the extraction of titanium from it.

Titanium metal production consumes a small proportion of total titanium reserves per year [7]. Low density and high tensile strength make titanium attractive for industrial applications, and give titanium-containing alloys the highest strength-to-weight ratio, an important property for metals in the steel industry. In addition, titanium is a valuable metal and can resist corrosion of both seawater and acids. As an alloyed metal, it can also resist corrosion better than copper and nickel alloys and has a low modulus of elasticity that is half that of steel and nickel alloys. The most common titanium alloy is Ti6A-4V ( $6 \%$ aluminum, $4 \%$ vanadium, $90 \%$ titanium) and is typically used in medical applications such as knee replacement implants. Metal is also one of the main elements in the aerospace industry, architecture, chemical, and automotive applications [10].

The traditional methods of manufacturing Ti follow the same general procedures as steel, including the primary metal production, the melting and casting of alloy ingots, forging and rolling to produce rolling products, and the manufacture of components or structures from rolling products [11]. Many powder production processes are at various stages of development. There are two general approaches for Ti metal production: electrochemical and thermochemical methods. The well-known example of the electrochemical methods is the Fray, Farthing, and Chen (FFC) or Cambridge process [12], which is based on the electrolysis reduction of titanium oxide. The Kroll process [13], is an example of the thermochemical way that is a commercially suitable process for primary Ti metal production today.

This review provides an overview of titanium resources, of which ilmenite is the main source, as well as it focuses on some effective methods for producing titanium powder through extractive metallurgy processes, and highlights a comprehensive view of the opportunities and challenges.

\section{Titanium Usage and Market}

Titanium, and particularly titanium alloys, have become economically accessible following a drop of nearly $30 \%$ in the price of commercially pure titanium over the last five years [14]. Titanium alloys have many physical (lightness, good mechanical properties, resistance to cryogenic temperatures) and chemical (resistance to electrochemical corrosion, biocompatibility) advantages $[15,16]$, which make them an indispensable material for civil and military applications in fields as vast as in energy, transport, medical (MRI magnet for observing the human body), water treatment, and the transport of corrosive liquids and gases (Figure 1) [14].

The uses of titanium have expanded based on its inherent properties as well as the development of new alloys. The main use is still in aerospace and aeronautics applications, such as engines, airframes, missiles, and spacecraft [16]. Aerospace applications are based on the low density (Table 1) and high strength-to-weight ratio of titanium alloyed at high temperatures. Titanium's corrosion resistance makes it a natural material for seawater, marine, and naval applications. In addition, titanium is largely used in seawater-cooled power plant capacitors [16]. 


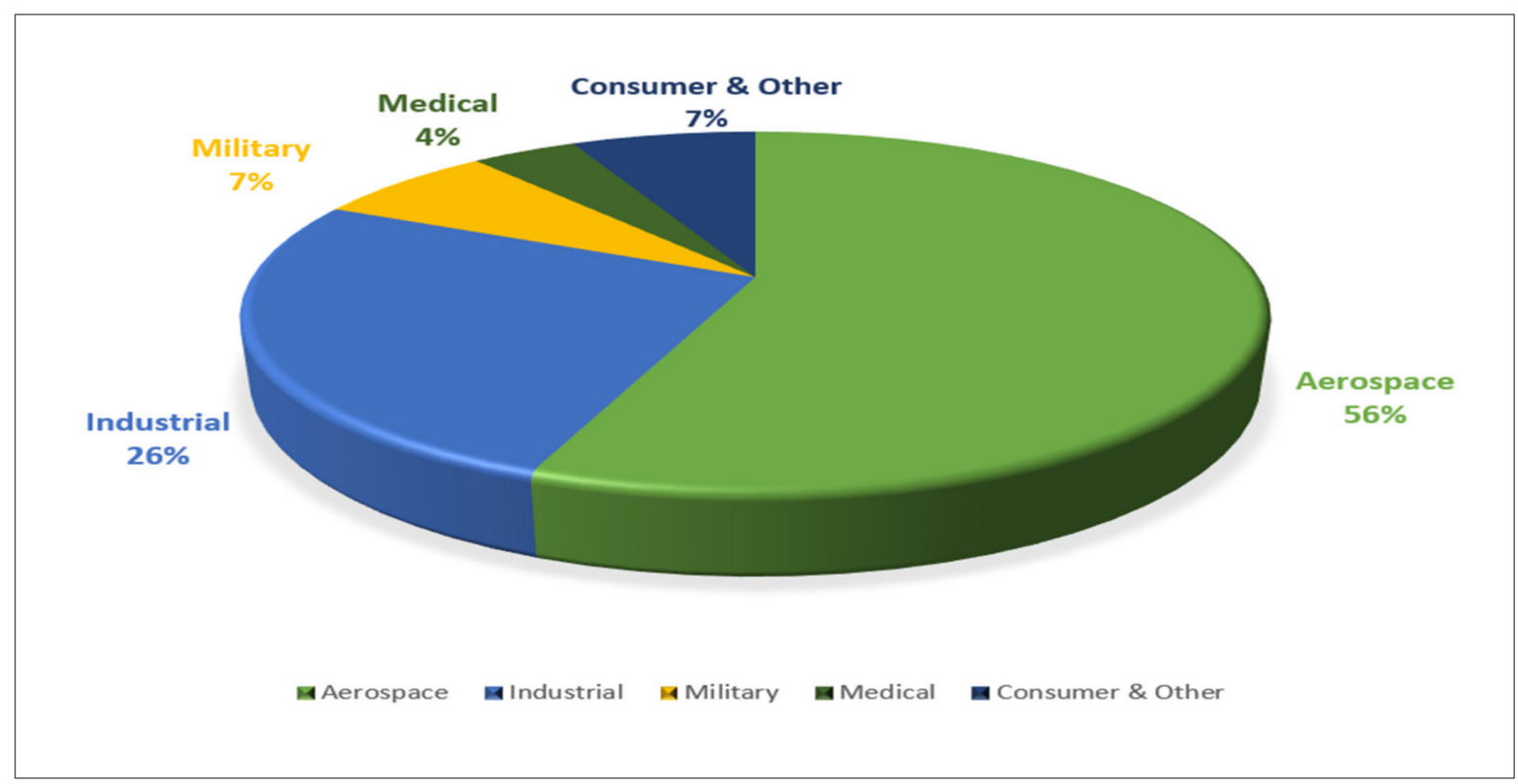

Figure 1. Titanium applications of the Western world by market sector, 2017 [17] (Reprinted with permission from Elsevier, Copyright, (2020)).

Table 1. Some properties of pure titanium $[15,16]$.

\begin{tabular}{|c|c|}
\hline Parameter & Value \\
\hline Atomic number & 22 \\
\hline Atomic radius $(\AA)$ & 1.47 \\
\hline Atomic weight & 47.9 \\
\hline Boiling point $(\mathrm{K})$ & 3273 \\
\hline Chemical valence & $2,3,4$ \\
\hline Electrical resistivity & $42.06 \times 10^{-6}$ \\
\hline Ion radius $(\AA) \mathrm{Ti}^{+2}$ & 0.9 \\
\hline Ion radius $(\AA) \mathrm{Ti}^{+4}$ & 0.68 \\
\hline Melting point (K) & 2073 \\
\hline Density $\left(\mathrm{g} / \mathrm{cm}^{3}\right)$ & 4.51 \\
\hline Specific heat $(\mathrm{J} / \mathrm{kg}-\mathrm{K})$ & 519 \\
\hline Traction modulus $\times 10^{3}(\mathrm{MPa})$ & 101 \\
\hline Modulus of elasticity $\times 10^{3}(\mathrm{MPa})$ & 103 \\
\hline Hardness (1500 kg load) (HB) & 65 \\
\hline Fatigue resistance & $0.5-0.6$ \\
\hline
\end{tabular}

Titanium can also be utilized in petroleum refineries, paper, and pulp bleaching operations, nitric acid plants, and some organic synthesis production [4]. Moreover, Titanium has found its use in the medical field. In particular, depending on clinical needs, titanium and a multitude of its alloys offer high axial flexibility, good expansion behavior, radio-opacity, and hemocompatibility. Even of its sophisticated bio-applications, the main use of titanium in biomedicine is as a structural prosthesis $[1,2,18]$.

\section{Resources}

Titanium deposits are huge, with current estimates assuming a global reserve of 650 billion metric tons of titanium oxide. The minable deposits are found in South Africa at Namaqualand and Richards Bay, Australia, Canada, Norway, and Ukraine (Figure 2) [1,7]. The two main minerals being considered for use are ilmenite and rutile and although these are the minerals available for economic mining, $\mathrm{TiO}_{2}$ is part of almost every mineral, sand, and rock [4]. 


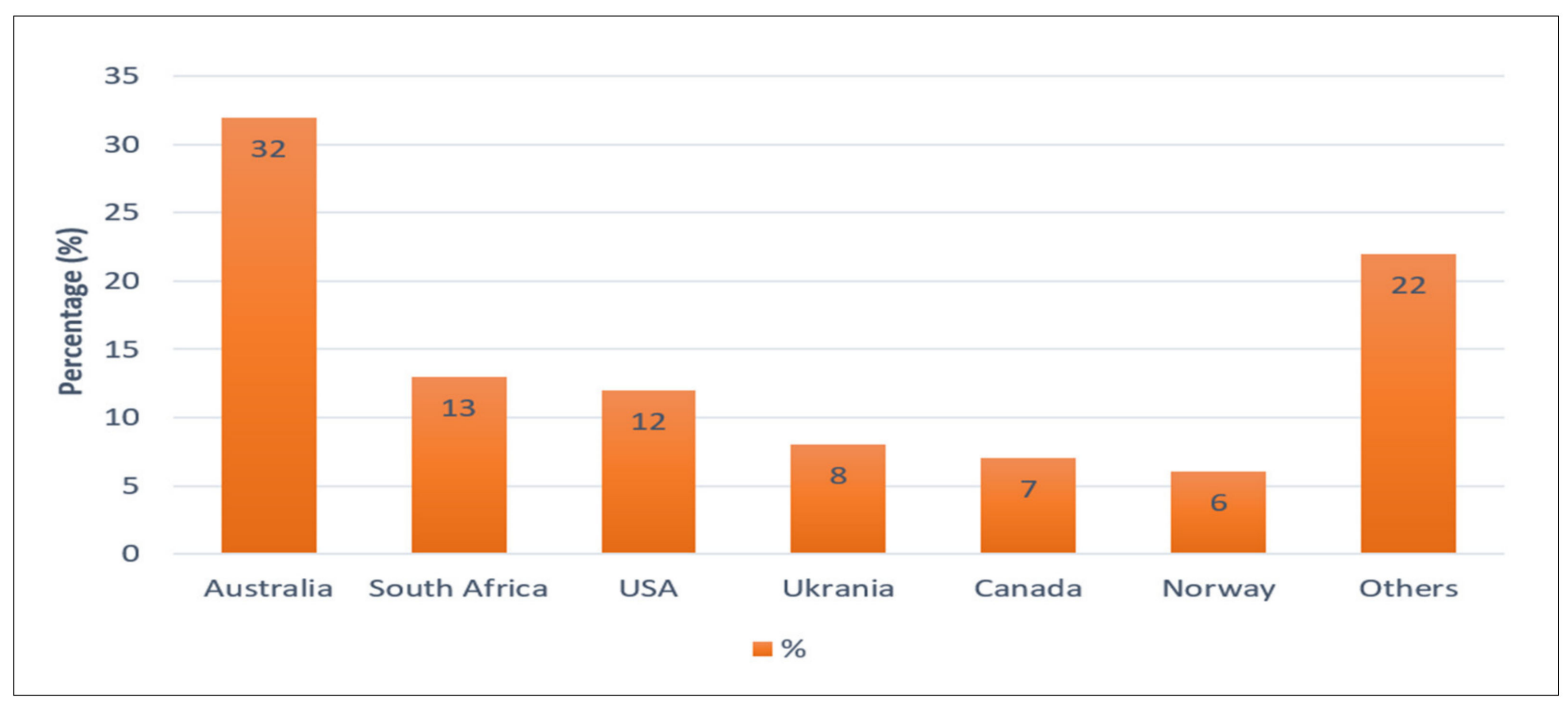

Figure 2. Distribution of the titanium ore reserves in the world $[1,4]$.

The common titanium minerals are anatase, brookite, leucoxene, perovskite, titanite, rutile, and ilmenite. However, only ilmenite, leucoxene, and rutile have crucial commercial value. Ilmenite and rutile are the two main titanium minerals used in industrial applications, mainly for titanium metal production and pigment-grade titanium dioxide [19].

\section{Mineral Ilmenite}

In 1827, Adolph Theodor Kupffer discovered Ilmenite (titanoferrite) in the Ilmen Mountains of Russia. $\mathrm{FeTiO}_{3}$ is the typical chemical formula of ilmenite, while its chemical composition is (40-65 wt.\%) $\mathrm{TiO}_{2}$ and (35-60 wt.\%) $\mathrm{Fe}_{2} \mathrm{O}_{3}$ [20]. Table 2 shows the properties of pure ilmenite.

Table 2. Basic properties of pure ilmenite $\left(\mathrm{FeTiO}_{3}\right)$ [21].

\begin{tabular}{cc}
\hline Property & Value \\
\hline Chemical classification & Oxide \\
Color & Black \\
Luster & Metallic, sub-metallic \\
Mohs hardness & $5-6$ \\
Specific weight & $4.7-4.8 \mathrm{~g} / \mathrm{cm}^{3}$ \\
Crystalline structure & Hexagonal \\
Cleavage & Absent \\
Unit cell & $\mathrm{a}=\mathrm{b}=508.854 \AA$ 的 $=14.0924 \AA$ \\
\hline
\end{tabular}

Ilmenite is an economically important mineral, mainly because of its role in the production of titanium oxide pigments. Its magnetic properties and those of ilmenitehematite solid solutions $\left(\mathrm{Fe}_{2} \mathrm{O}_{3} ;\right)$ are particularly important in commercial extraction by magnetic separation. The dependence of the ilmenite structure on temperature, pressure, and composition is strongly related to its electronic, magnetic, and optical properties [22]. Due to the coexistence of ilmenite with geikielite $\left(\mathrm{MgTiO}_{3}\right)$ and pyrophanite $\left(\mathrm{MnTiO}_{3}\right)$ in these rocks, the typical chemical formula of this mineral in magmatic rocks is ( $\mathrm{Fe}, \mathrm{Mn}, \mathrm{Mg}$ ) $\mathrm{TiO}_{3}$ [21]. Ilmenite is often confused with other iron-bearing minerals such as hematite and magnetite because of its high magnetic susceptibility (Figure 3). Ilmenite has a hexagonal crystal structure that is similar to corundum $\left(\mathrm{Al}_{2} \mathrm{O}_{3}\right)$ and different from other iron minerals and has lower magnetism compared to hematite and magnetite. The crystal presents an octahedral structure alternating and coordinated with iron and titanium layers $[22,23]$. 

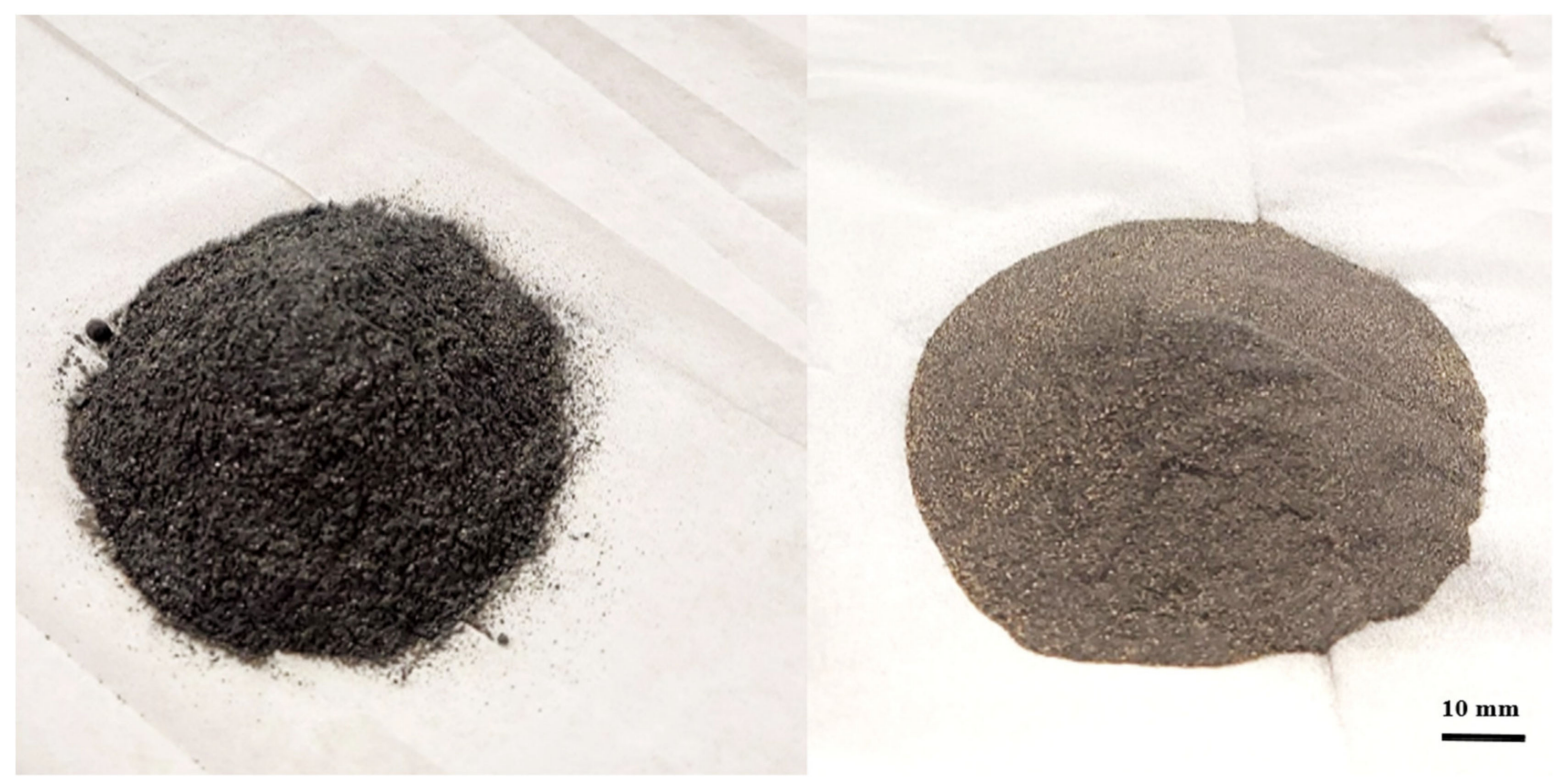

Figure 3. Ilmenite sand (left) and grinded material (right) from the Metchib company, Quebec, Canada.

The Tellnes (Norway) mines produce 550,000 tons of ilmenite per year [24]. The largest Ti producers in the world are China, Australia, and South Africa (Figure 4). China produces ilmenite in significant quantities, while Australia and South Africa have the world's largest natural reserves for ilmenite and rutile $[7,21]$.

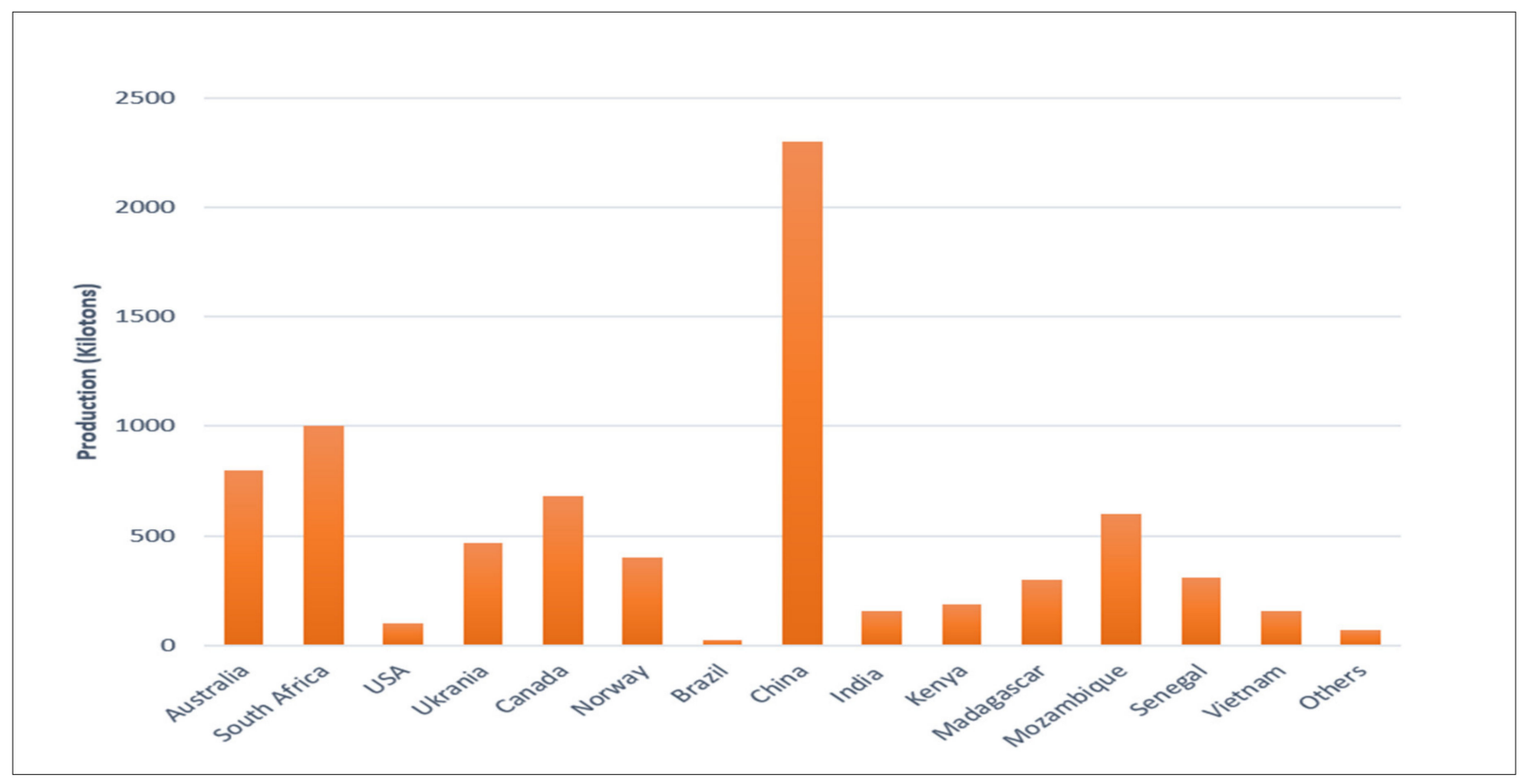

Figure 4. Ilmenite mine production in different countries in 2020 [7].

\section{Metallurgical Extraction of Titanium from Its Concentrates}

Many methods are used for the production of Ti metal powder. Ti powder is, therefore, the product of extraction processes that produce primary metal by using titanium tetrachloride $\left(\mathrm{TiCl}_{4}\right)$ or titanium dioxide $\left(\mathrm{TiO}_{2}\right)$ as feed material $[25,26]$. Processes for the manufacture of titanium powder directly as extractive metallurgical products include the manufacture of $\mathrm{Ti}$ from $\mathrm{TiCl}_{4}$, purified $\mathrm{TiO}_{2}$, and/or improved titanium slag (UGS) with a $\mathrm{TiO}_{2}$ content greater than $90 \%$. Upgraded titanium slag (UGS) is one of the fundamental 
products of the carbothermal reduction of titanium ore such as ilmenite. Natural rutile and synthetic rutile are also included in this raw material category. These processes can be categorized: (1) thermochemical methods and (2) electrochemical methods [11].

\subsection{Thermochemical Processes}

\subsubsection{Kroll Process}

The commercial production of primary Ti metal is generally made either by Kroll [13] or Hunter processes [27]. The standard process against which new technologies are compared is the Kroll process (Figure 5).

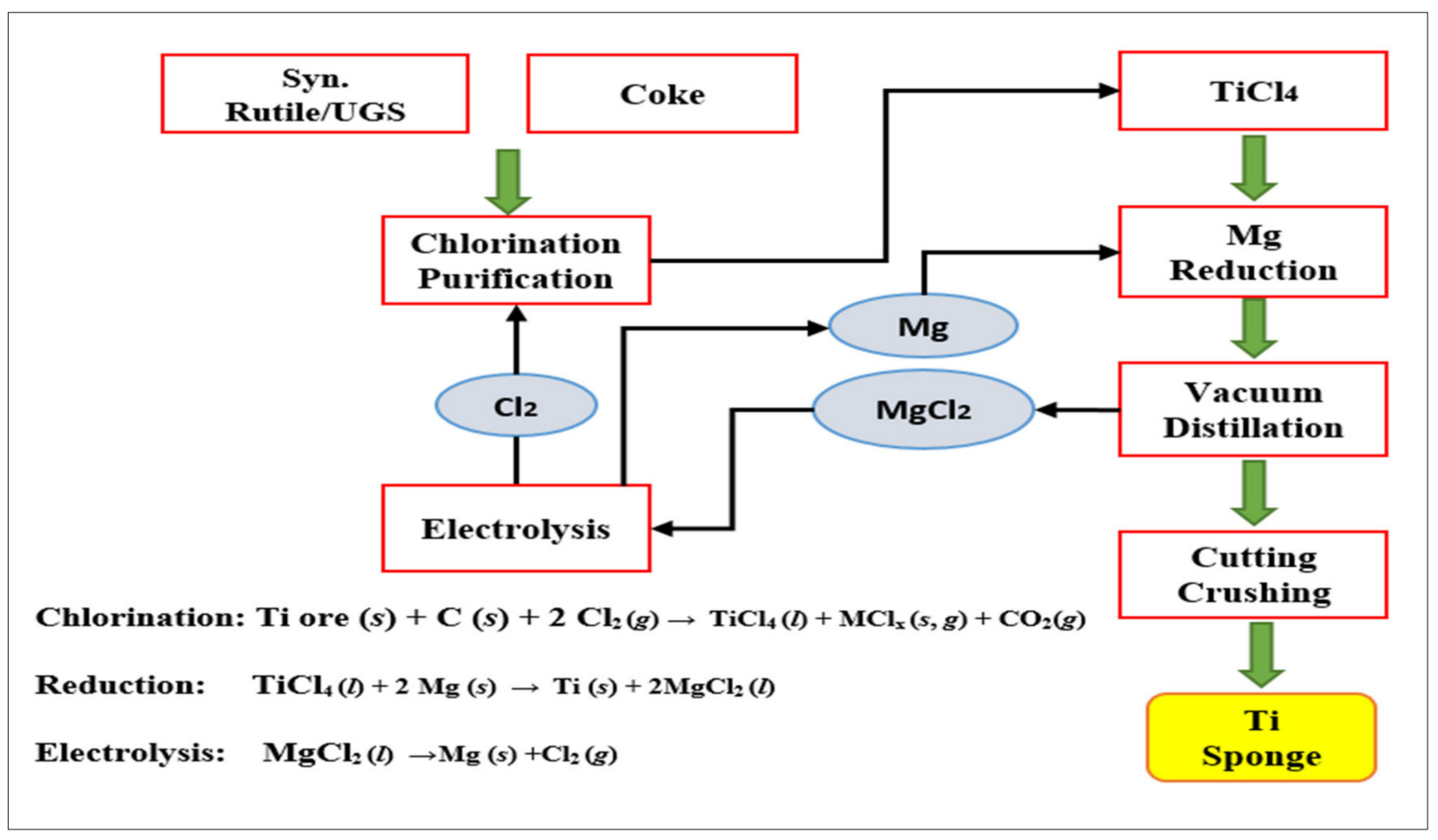

Figure 5. Scheme and reactions of the Kroll process of titanium sponge production [28] (Reprinted with permission from Springer Nature, Copyright, (2020)).

In the process, magnesium metal (the reducing agent) is injected into a retort filled with argon and heated to $800-900{ }^{\circ} \mathrm{C}$. However, the oxides impurity contained in the Ti slag is also chlorinated, so refined $\mathrm{TiCl}_{4}$ has been produced by purifying the crude $\mathrm{TiCl}_{4}$ before the $\mathrm{Mg}$ reduction [13,29]. Although most of the by-product $\mathrm{MgCl}_{2}$, and excess magnesium, is drained during reduction, the product sponge contains residual magnesium and $\mathrm{MgCl}_{2}$ in its porosity [30]. Magnesium and $\mathrm{MgCl}_{2}$ are separated by vacuum distillation or helium sweeping followed by leaching. Part of the sponge must be decommissioned due to contamination of the autoclave wall $[13,29]$.

According to one estimate, $70 \%$ of the total energy consumption is considered for the distillation to produce the sponge metal. It shows that the cost of metal purification is one of the major cost drivers, in addition to the cost of the precursor and reductant [30].

\subsubsection{Hunter Process}

The popular process established on $\mathrm{TiCl}_{4}$ reduction using $\mathrm{Na}$ is the Hunter process. The Hunter and Kroll processes are quite similar in that they are considered as thermochemical processes based on the reduction of $\mathrm{TiCl}_{4}$ to produce $\mathrm{Ti}$ [27]. Economically, the Hunter process is considered non-competitive with the Kroll process. The main difficulty is that to produce one mole of $\mathrm{Ti}$ by reducing $\mathrm{TiCl}_{4}$ requires four moles of $\mathrm{Na}$, whereas only two moles of $\mathrm{Mg}$ are needed for 1 mole of Ti [11]. In addition, producing Na by electrolysis 
is at least as expensive as that of $\mathrm{Mg}$. These problems make the processing of $\mathrm{Na}$ more expensive than the use of Mg. However, the Hunter process can also produce Ti powder instead of Ti sponge [31].

In the Hunter process, $\mathrm{TiCl}_{4}$ and $\mathrm{Na}$ are gradually introduced into the reactor. The process is generally performed over $800{ }^{\circ} \mathrm{C}[28,32]$. Ti is formed at the surface of the molten bath, where the gas $\mathrm{TiCl}_{4}$ is exposed to the $\mathrm{Na}$. Ti crystals then form and are set at the bottom of the liquid bath. According to the operating parameters, some $\mathrm{Ti}$ particles can form Ti sponge, while others are deposited as Ti powder. The purity of the powder produced by the Hunter process is often higher $(99 \%)[11,29]$. Table 3 provides a comparison between Kroll and Hunter processes.

Table 3. Comparison between Kroll and Hunter processes [31] (Reprinted with permission from John Wiley and Sons, Copyrright, (2013)).

\begin{tabular}{|c|c|}
\hline Kroll & Hunter \\
\hline Batch & Does not last forever \\
\hline $15-50 \%$ excess magnesium & A small excess of $\mathrm{TiCl}_{4}$ \\
\hline Few fines & Up to $10 \%$ fines \\
\hline Difficult to rectify & Easy to rectify \\
\hline Heavy iron contamination from the walls of the autoclave & Little iron contamination from retort walls. \\
\hline Sponge washed or vacuum distilled & Sponge leached \\
\hline Retort contains mostly titanium & Retort contains 4 moles of $\mathrm{NaCl}$ for each mole of titanium \\
\hline
\end{tabular}

\subsubsection{Armstrong Process}

The Armstrong process is considered the most advanced process. It uses the same reactions as the Hunter process [33].

Therefore, the crucial advantage of the Armstrong process [34] is the continuity of the operation, pumping molten sodium in the reactor to react continuously with $\mathrm{TiCl}_{4}$ gas (Table 4). Ti powder and the resulting $\mathrm{NaCl}$ are collected from the reactor by the sodium stream. Once the unreacted liquid $\mathrm{Na}$ is removed by filtration, as well as Ti powder is purified by washing out the salt. The Armstrong product can be described as mini sponges, i.e., microporous particles [35]. Figure 6 shows the Armstrong process aspects.

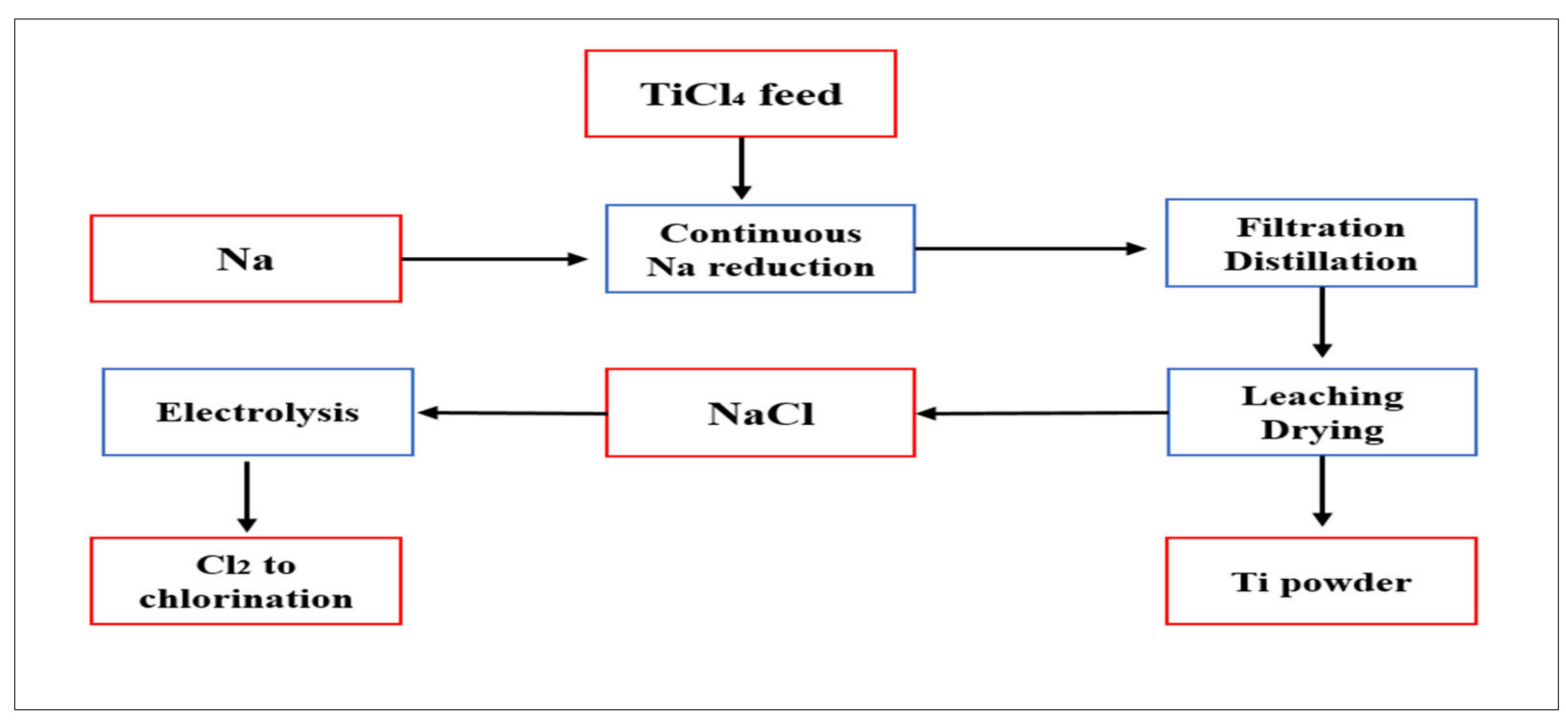

Figure 6. The Armstrong flow diagram [36]. 


\subsubsection{TiRO Process}

This process was developed by CSIRO (Commonwealth Scientific and Industrial Research Organization) in Australia and used the same reactions as the Kroll process but in a fluidized bed reactor in which gas-solid fluidization takes place, which considerably increases the reaction rate and reduces both operating and capital costs [37].

The TiRO process consists of two main steps (Figure 7): reduction of $\mathrm{TiCl}_{4}$ in a fluidized bed with $\mathrm{Mg}$ powder and vacuum distillation to remove the by-products $\mathrm{MgCl}_{2}$ and $\mathrm{Mg}$ [38].

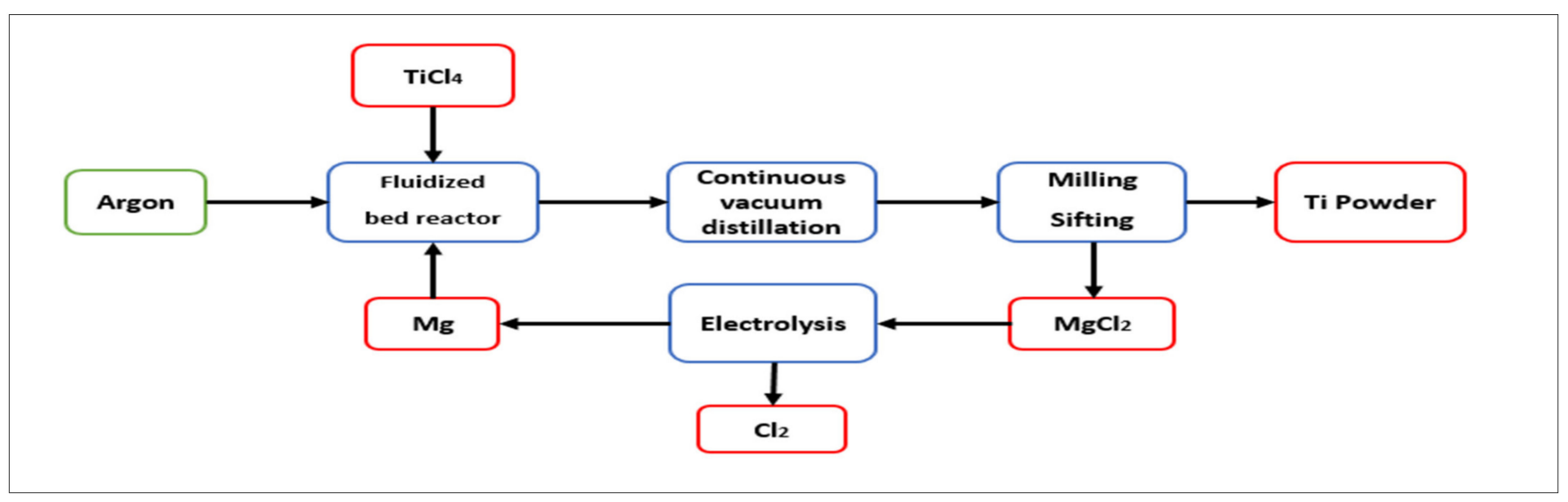

Figure 7. Diagram of the process TiRO ${ }^{\mathrm{TM}}$ [39].

According to the information mentioned above, $\mathrm{TiCl}_{4}$ can be reduced by sodium or magnesium. The main characteristics of the powder are well detailed in Table 4 below.

All these processes below use $\mathrm{TiO}_{2}$ as raw material to produce titanium powder with high purity. 
Table 4. Comparison between characteristics of $\mathrm{TiCl}_{4}$ reduction-based processes (adapted from [11] Taylor \& Francis, an open-access journal).

\begin{tabular}{|c|c|c|c|c|c|c|c|c|c|}
\hline Category & $\begin{array}{l}\text { Process } \\
\text { Identifier }\end{array}$ & $\begin{array}{c}\text { Raw } \\
\text { Material }\end{array}$ & $\begin{array}{l}\text { Reducing } \\
\text { Agent }\end{array}$ & $\begin{array}{l}\text { Product Size and } \\
\text { Morphology }\end{array}$ & $\begin{array}{l}\text { Reported } \\
\text { Chemical Product } \\
\text { and Composition }\end{array}$ & $\begin{array}{l}\text { Batch or } \\
\text { Continuous: } \\
\text { Reactions }\end{array}$ & Salt & $\operatorname{Temp}\left({ }^{\circ} \mathrm{C}\right)$ & Ref \\
\hline \multirow{4}{*}{$\begin{array}{l}\text { Reducing } \mathrm{TiCl}_{4} \\
\quad \text { using } \mathrm{Mg}\end{array}$} & Kroll & $\mathrm{TiCl}_{4}$ & Mg Liquid & Sponge & $\mathrm{O} \sim 0.06 \%$ & $\begin{array}{c}\text { Batch; } \\
2 \mathrm{Mg}+\mathrm{TiCl}_{4} \rightarrow \mathrm{Ti}+ \\
2 \mathrm{MgCl}_{2}\end{array}$ & No salt & 800-1000 & [13] \\
\hline & TiRO & $\mathrm{TiCl}_{4}$ & Mg Powder & $\begin{array}{l}\text { Similar spherical shape } \\
\text { but sintered to form } \\
\text { large chunks }\end{array}$ & $\begin{array}{l}\mathrm{O} \geq 0.3 \% \\
\mathrm{Cl}<0.03 \%\end{array}$ & $\begin{array}{c}\text { Continuous; } \\
2 \mathrm{Mg}+\mathrm{TiCl}_{4} \rightarrow \mathrm{Ti}+ \\
2 \mathrm{MgCl}_{2}(\mathrm{~s})\end{array}$ & No salt & $650-712$ & {$[38]$} \\
\hline & $\begin{array}{l}\text { Vapor Phase } \\
\text { Reduction }\end{array}$ & $\mathrm{TiCl}_{4}$ & Mg Vapor & $\begin{array}{l}\text { Sub-micrometer, too fine } \\
\text { to be captured }\end{array}$ & $\begin{array}{l}\text { Low levels of } \mathrm{Mg} \\
\text { and } \mathrm{Cl} \text {, but } \\
\mathrm{O} \geq 0.82 \% \text {. }\end{array}$ & $\begin{array}{c}\text { Continuous; } \\
2 \mathrm{Mg}+\mathrm{TiCl}_{4} \rightarrow \mathrm{Ti}+ \\
2 \mathrm{MgCl}_{2}\end{array}$ & No salt & 1000 & [40] \\
\hline & CSIR-Ti & $\mathrm{TiCl}_{4}$ & $\mathrm{Mg}$ & $\begin{array}{l}\text { Irregular shape, size be } \\
\text { ranging from } 1 \text { to } \\
330 \mu \mathrm{m}\end{array}$ & $\begin{array}{l}\mathrm{Cl}<50 \mathrm{ppm} \\
\mathrm{N}<50 \mathrm{ppm} \\
\mathrm{O}>0.2 \%\end{array}$ & $\begin{array}{c}\text { Continuous; } \\
\mathrm{Mg}+\mathrm{TiCl}_{4} \rightarrow \mathrm{TiCl}_{2}+ \\
\mathrm{MgCl}_{2} \mathrm{TiCl}_{2}+\mathrm{Mg} \rightarrow \mathrm{Ti}+ \\
\mathrm{MgCl}_{2}\end{array}$ & No salt & $>900$ & {$[41]$} \\
\hline \multirow{2}{*}{$\begin{array}{l}\text { Reducing } \mathrm{TiCl}_{4} \\
\text { using Na }\end{array}$} & Hunter & $\mathrm{TiCl}_{4}$ & $\mathrm{Na}$ & Sponge and powder & $\begin{array}{l}\text { Purer than that } \\
\text { produced by the } \\
\text { Kroll process } \\
(99 \%)\end{array}$ & $\begin{array}{c}\text { Batch; } \\
4 \mathrm{Na}+\mathrm{TiCl}_{4} \rightarrow \mathrm{Ti}+4 \mathrm{NaCl}\end{array}$ & No salt & $>800$ & {$[27,42]$} \\
\hline & ARC & $\mathrm{TiCl}_{4}$ & $\mathrm{Na}$ & $\begin{array}{l}\text { Powder, small } \\
\text { aggregates }\end{array}$ & $\begin{array}{l}\text { Oxide layer } \\
\text { contributes a lot to } \\
\text { the final high } \\
\text { oxygen content }\end{array}$ & $\begin{array}{c}\text { Continuous; } \\
2 \mathrm{Na}+\mathrm{TiCl}_{4} \rightarrow \mathrm{TiCl}_{2}+ \\
2 \mathrm{NaCl} \\
\mathrm{TiCl}_{2}+2 \mathrm{Na} \rightarrow \mathrm{Ti}+2 \mathrm{NaCl}\end{array}$ & No salt & $>800$ & [43] \\
\hline
\end{tabular}




\subsubsection{Metal Hydride Reduction (MHR) Process}

The MHR process was first introduced in 1945, and the most remarkable work was reported by Borok [44], in 1965 and Froes et al. in 1998 [45]. Calcium hydride was used to directly reduce $\mathrm{TiO}_{2}$. In Russia, a commercial operation has been reported that uses the same procedure [46].

\subsubsection{Electronically Mediated Reduction (EMR) Process}

EMR process uses calcium as a reducing agent to produce titanium. The $\mathrm{TiO}_{2}$ reduction is made with no direct contact with the reducing $\mathrm{Ca}-\mathrm{Ni}$ alloy, and hence the contamination of titanium can be successfully avoided by using EMR. This approach can be exploited to develop another process to produce titanium powder continuously [47].

\subsubsection{Process for Reducing Preforms}

Okabe et al. [48] have developed this process where $\mathrm{TiO}_{2}$ is mixed with either $\mathrm{CaO}$ or $\mathrm{CaCl}_{2}$ and sintered in the air. Calcium vapor reduces $\mathrm{TiO}_{2}$ at temperatures between 800 and $1000{ }^{\circ} \mathrm{C}$, with the calcium oxide dissolving in calcium chloride. A hydrochloric acid solution has been used for leaching the product [46]. Again, these experiments were only conducted in the laboratory [49].

\subsubsection{Hydrogen-Assisted Magnesium Reduction (HAMR) Process}

The HAMR process is developed to produce a Ti powder with a very low oxygen content, by using a hydrogen atmosphere, molten salt, and deoxygenation step to guarantee that the oxygen amount in titanium powder is sufficiently low (less than $0.15 \%$ by weight) $[50,51]$. Table 5 shows a comparison between the characteristics of these processes based on $\mathrm{TiO}_{2}$ reduction.

Table 5. Comparison between characteristics of $\mathrm{TiO}_{2}$ reduction-based processes (reprinted from [11] Taylor and Francis, an open-access journal).

\begin{tabular}{|c|c|c|c|c|c|c|c|}
\hline $\begin{array}{l}\text { Process } \\
\text { Identifier }\end{array}$ & $\begin{array}{c}\text { Raw } \\
\text { Material }\end{array}$ & $\begin{array}{l}\text { Reducing } \\
\text { Agent }\end{array}$ & $\begin{array}{c}\text { Product Size } \\
\text { and } \\
\text { Morphology }\end{array}$ & $\begin{array}{l}\text { Reported Chemical } \\
\text { Product and } \\
\text { Composition }\end{array}$ & Salt & $\begin{array}{c}\text { Temperature } \\
\left({ }^{\circ} \mathrm{C}\right)\end{array}$ & Ref \\
\hline MHR & $\mathrm{TiO}_{2}$ & $\mathrm{CaH}_{2}$ & $\begin{array}{l}\text { Irregular, } \\
\text { sponge }\end{array}$ & $\begin{array}{c}\text { O: } 0.19 \text { wt. } \%, \mathrm{H}: \\
0.34 \text { wt. } \%, \mathrm{C}: \\
0.03 \text { wt. } \%, \mathrm{~N}: \\
0.06 \text { wt. } \%\end{array}$ & No salt & $1100-1200$ & {$[52,53]$} \\
\hline $\begin{array}{l}\text { Calciothermal } \\
\text { reduction }\end{array}$ & $\mathrm{TiO}_{2}$ & $\mathrm{Ca}$ & $\begin{array}{l}\text { Irregular, } \\
\text { sponge }\end{array}$ & $\begin{aligned} \text { O: } & <0.2 \text { wt. } \% \text {, Ca: } \\
& >0.1 \text { wt. } \%\end{aligned}$ & $\mathrm{CaCl}_{2}$ & $900-1200$ & [54] \\
\hline $\begin{array}{l}\text { Process for } \\
\text { reducing } \\
\text { preforms }\end{array}$ & $\mathrm{TiO}_{2}$ & $\mathrm{Ca}$ & $\begin{array}{l}\text { Irregular, } \\
\text { sponge }\end{array}$ & O: $0.2-0.3$ wt. $\%$ & $\mathrm{CaCl}_{2}$ & $>900$ & [48] \\
\hline EMR & $\mathrm{TiO}_{2}$ & $\mathrm{Ca}$ & $\begin{array}{l}\text { Irregular, } \\
\text { sponge }\end{array}$ & O: $0.15-0.2$ wt. $\%$ & $\begin{array}{c}\mathrm{CaCl}_{2} \text { or } \mathrm{CaCl}_{2} \\
+\mathrm{CaO}\end{array}$ & $>900$ & {$[47,55]$} \\
\hline $\begin{array}{l}\text { Combustion } \\
\text { synthesis }\end{array}$ & $\mathrm{TiO}_{2}$ & $\mathrm{Mg}+\mathrm{Ca}$ & $\begin{array}{l}\text { Irregular, } \\
\text { sponge }\end{array}$ & O: $0.2-0.3$ wt. $\%$ & $\mathrm{Ca}(\mathrm{OH})_{2}$ & 850-1000 & {$[56,57]$} \\
\hline HAMR & UGS & $\mathrm{Mg}+\mathrm{Ca}$ & $\begin{array}{l}\text { Dense, } \\
\text { globular } \\
\text { powder }\end{array}$ & O: $<0.15$ wt. $\%$ & $\begin{array}{l}\mathrm{MgCl}_{2} \text { or } \\
\mathrm{MgCl}_{2}-\mathrm{KCl}\end{array}$ & $<800$ & {$[50,58]$} \\
\hline
\end{tabular}

There have been several reports and trials to perform continuous processes based on the same chemistry as the above processes. Lu et al. [59] produced a fine titanium powder from a titanium sponge by the shuttle: the disproportionation reaction and its reverse reaction (proportioning reaction) of titanium ions in molten $\mathrm{NaCl}-\mathrm{KCl}$ at $750{ }^{\circ} \mathrm{C}$. Moreover, some experiments were performed to synthesize $\mathrm{TiH}_{2}$ from the reaction between $\mathrm{CaH}_{2}$ and $\mathrm{TiCl}_{4}$ in the presence of $\mathrm{Ni}[60]$. 
In another study, porous titanium was obtained in mixtures of molten $\mathrm{CaO}-\mathrm{CaCl}_{2}$ salts dissolved in Ca by self-sintering with the exothermic reaction between porous $\mathrm{CaTiO}_{3}$ and calcium vapor at $1000{ }^{\circ} \mathrm{C}$ for $6 \mathrm{~h}$ under vacuum [61]. Development of a new method based on deoxidation of dissolved $\mathrm{O}$ from Ti. The process leads to the formation of $\mathrm{YOCl}$ using $\mathrm{Mg}$ as a deoxidizer at $1027^{\circ} \mathrm{C}$ [62].

Daniel Spreitzer et al. [63] have used a laboratory fluidized bed reactor to cut down the hematite kinetic reaction to produce Fe by hydrogen around $600-800{ }^{\circ} \mathrm{C}$ by measuring the change in weight of the sample portion during reduction. Moreover, with combining magnesiothermal reduction of $\mathrm{TiO}_{2}$ and a leaching purification process, titanium metal powder was obtained with only $2.98 \%$ of O [64]. The synthesis of a cermet based on Fe-TiC by carbothermal reduction of ilmenite was successfully produced [65]. This method was done in an atmosphere containing argon in a scope of $850-1350^{\circ} \mathrm{C}$. Another study has led to developing an environmentally friendly pre-treatment process to recycle titanium turning waste and ferrotitanium ingots with low levels of gaseous impurities [66]. The number of gaseous impurities in the titanium scrap before the removal of machining oils from the surface reached $2 \%$ [66]. Similarly, Nersisyan et al. [67] have developed a combustion synthesis route for single-phase titanium-based compounds (e.g., $\mathrm{FeTi}, \mathrm{TiC}, \mathrm{TiB}_{2}$, and $\mathrm{TiFeSi}_{2}$ ) from the precursor mixture $\mathrm{FeTiO}_{3}$ (natural ilmenite)- $\alpha \mathrm{Mg}-\mathrm{C}(\mathrm{B}, \mathrm{Si})-\mathrm{kNaCl}$. The method allows the process temperature and the phase composition to be controlled by changing the number of moles of $\mathrm{Mg}$ and $\mathrm{NaCl}$ [67]. Furthermore, new research has been developed to study the effect of the degree of ilmenite reduction on the chemical and phase characteristics of ferrotitanium and slag produced by the SHS aluminothermic process, which is a highly exothermic thermite reaction [68]. Increasing reduction not only reduces the consumption of aluminum and the amount of slag produced in the preparation of ferrotitanium but also reduces the oxygen content and improves the titanium and iron qualities [68]. Further, the Panzhihua ilmenite carbothermal reduction with activated carbon has been studied by using isothermal trials between $1200^{\circ} \mathrm{C}$ and $1500{ }^{\circ} \mathrm{C}$ [69]. By decreasing the pressure and increasing the temperature, the impurities $(\mathrm{Mg}, \mathrm{Mn})$ in the product have been removed [69]. The carbothermal reduction behavior of ilmenite at high temperatures was studied by thermodynamic calculations [70]. FeTi formation is generated at $1650^{\circ} \mathrm{C}$. By increasing the temperature, a clear increase of $\mathrm{TiC}$ is observed, which can also encourage the further reduction of ilmenite slag at high temperatures [70].

Otherwise, for patents published in this sense, Mu et al. [71] invented a method that aimed to improve the metallic titanium production with a low-energy titanium-containing material by a molten salt electrolysis process (Table 6).

Similarly, in 2016, Fang et al. [51] presented a research procedure for producing a titanium powder or sponge. For instance, the method may include obtaining a $\mathrm{TiO}_{2}$-rich material, reducing impurities to produce purified $\mathrm{TiO}_{2}$, reducing the purified $\mathrm{TiO}_{2}$, using a metallic reducer at the same temperature and pressure to produce a $\mathrm{TiH}_{2}$ product [51]. RMI (now part of Arconic) has patented a process that carries out above $900{ }^{\circ} \mathrm{C}$ to reduce oxygen in Ti-6Al-4V powder [72]. 
Table 6. Advantages and disadvantages of some patents in titanium production based on thermochemical methods.

\begin{tabular}{|c|c|c|c|c|}
\hline Publication $\mathrm{N}^{\circ}$ & Title & Advantages & Disadvantages & Reference \\
\hline $\begin{array}{l}\text { US 2016/0108497 } \\
\text { A1 } \\
(2016)\end{array}$ & $\begin{array}{c}\text { Methods of producing a titanium } \\
\text { product }\end{array}$ & 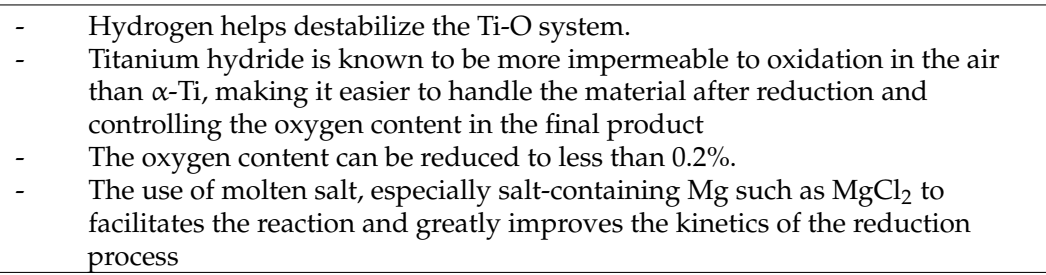 & $\begin{array}{ll}\text { - } & \text { High reduction temperatures } \\
\text { - } & \text { High pressures }\end{array}$ & [51] \\
\hline $\begin{array}{l}\text { US 9,963,796 B2 } \\
\quad(2018)\end{array}$ & $\begin{array}{l}\text { Method of producing titanium metal } \\
\text { with titanium-containing material }\end{array}$ & $\begin{array}{ll}- & \text { Low energy consumption } \\
- & \text { Low cost of production } \\
- & \text { Fewer titanium losses }\end{array}$ & Fine powder & [71] \\
\hline $\begin{array}{l}\text { US 10,066,308 B2 } \\
\text { (2018) }\end{array}$ & $\begin{array}{l}\text { System and method for extraction and } \\
\text { refining of titanium }\end{array}$ & $\begin{array}{ll}- & \text { Reduce the use of hazardous chemicals } \\
\text { - } & \text { Reduce the production of greenhouse gases, such as } \mathrm{CO}_{2} \\
\text { - } & \text { High purity up to } 90 \%\end{array}$ & $\begin{array}{ll}- & \text { High temperatures } \\
- & \text { Consumable anode } \\
- & \text { Relatively high energy consumption } \\
\end{array}$ & [73] \\
\hline $\begin{array}{l}\text { US 9,067.264 B2 } \\
\quad(2015)\end{array}$ & $\begin{array}{l}\text { Method of manufacturing pure titanium } \\
\text { hydride powder and alloyed titanium } \\
\text { hydride powders by combined } \\
\text { hydrogen-magnesium reduction of metal } \\
\text { halides }\end{array}$ & $\begin{array}{l}\text { To provide cost-effective and highly productive manufacturing of purified } \\
\text { titanium hydride powders and alloyed titanium hydride powders from } \\
\text { porous titanium compounds with reduced magnesium and hydrogen content } \\
\text { Reduce the thermal reduction reaction time in the horn by } 15 \% \text { to } 20 \% \text { and } \\
\text { simultaneously improve the percentage of magnesium used from } 40 \% \text { to } 50 \% \\
\text { to } 70 \% \text { to } 80 \%\end{array}$ & $\begin{array}{l}\text { - } \quad \text { Use of large quantities of hydrogen. } \\
\text { Production of small quantities of } \\
\text { titanium powder. } \\
\text { The use of hazardous chemicals such } \\
\text { as } \mathrm{TiCl}_{4 .}\end{array}$ & [74] \\
\hline $\begin{array}{l}\text { Re. } 34,598 \\
\quad(1994)\end{array}$ & Highly pure titanium & $\begin{array}{ll}- & \text { A fairly low temperature } \\
- & \text { Production of high purity titanium } \\
- & \text { Oxygen content does not exceed } 200 \mathrm{ppm}\end{array}$ & Contamination problem. & [76] \\
\hline $\begin{array}{l}\text { US } 4,923,531 \\
\quad(1990)\end{array}$ & $\begin{array}{l}\text { Deoxidation of titanium and similar } \\
\text { metals using a deoxidant in a molten } \\
\text { metal carrier }\end{array}$ & $\begin{array}{l}\text { - The process is effective for most refractory metal alloys } \\
\text { - } \quad \text { Low-pressure operation } \\
\text { The oxygen level can be reduced to between } 10 \text { and } 90 \% \text { of the initial oxygen } \\
\text { content, depending on the alloy and conditions }\end{array}$ & $\begin{array}{ll}\text { - } & \text { Deoxidation is limited; it concerns } \\
\text { metals and metal alloys containing } \\
\text { small quantities of oxygen } \\
\text { - } \quad \text { Fairly high temperature } \\
\text { - } \quad \text { Consumable proces }\end{array}$ & [72] \\
\hline
\end{tabular}


Table 6. Cont.

\begin{tabular}{|c|c|c|c|c|}
\hline Publication $\mathbf{N}^{\circ}$ & Title & Advantages & Disadvantages & Reference \\
\hline $\begin{array}{l}\text { US } 8,007,562 \text { B2 } \\
\quad(2011)\end{array}$ & $\begin{array}{l}\text { Semi-continuous magnesium-hydrogen } \\
\text { reduction process for manufacturing of } \\
\text { hydrogenated, purified titanium powder }\end{array}$ & $\begin{array}{ll}- & \text { Reaction temperatures are quite low } \\
- & \text { High productivity due to the use of a small mass of } \mathrm{TiCl}_{4} \\
- & \text { Less electricity consumption } \\
- & \text { Total powder production time is reduced }\end{array}$ & $\begin{array}{ll}- & \text { Use of high pressures. } \\
- & \text { A large amount of hydrogen } \\
- & \text { Use of large quantities of magnesium } \\
- & \text { Fine powder } \\
- & \text { The use of hazardous chemicals such } \\
& \text { as } \mathrm{TiCl}_{4 .}\end{array}$ & [77] \\
\hline $\begin{array}{l}\text { US } 10,689,730 \text { B2 } \\
(2020)\end{array}$ & $\begin{array}{c}\text { Methods of producing a titanium } \\
\text { product }\end{array}$ & Oxygen content can be reduced to less than $0.2 \%$ & Multi-step process & [78] \\
\hline $\begin{array}{c}\text { US } 583,492 \mathrm{~B} 2 \\
(2020)\end{array}$ & $\begin{array}{l}\text { Titanium powder production apparatus } \\
\text { and method }\end{array}$ & Preventing contamination of titanium powder & Preparation conditions are difficult & [79] \\
\hline
\end{tabular}




\subsection{Electrochemical Processes}

\subsubsection{Cambridge FFC Method}

For several decades, it was considered difficult to synthesize titanium with a low amount of oxygen. However, in 2000, a new method was introduced [80], which showed that it is possible to reduce $\mathrm{TiO}_{2}$, completely in the solid-state, to the metal in molten calcium chloride, which is a cheap and non-toxic product. This technique is known as the Cambridge FFC process (Figure 8). It operates in a molten saline environment, typically in the scope of $800{ }^{\circ} \mathrm{C}$ to $1100{ }^{\circ} \mathrm{C}$. $\mathrm{CaCl}_{2}$ is used as a salt since $\mathrm{CaCl}_{2}$ can dissolve and transport oxygen ions. The $\mathrm{TiO}_{2}$ reduction during the $\mathrm{FFC}$ process has been reached by the ionization of oxygen from the titanium-containing cathode, which diffuses to the anode and is discharged [46].

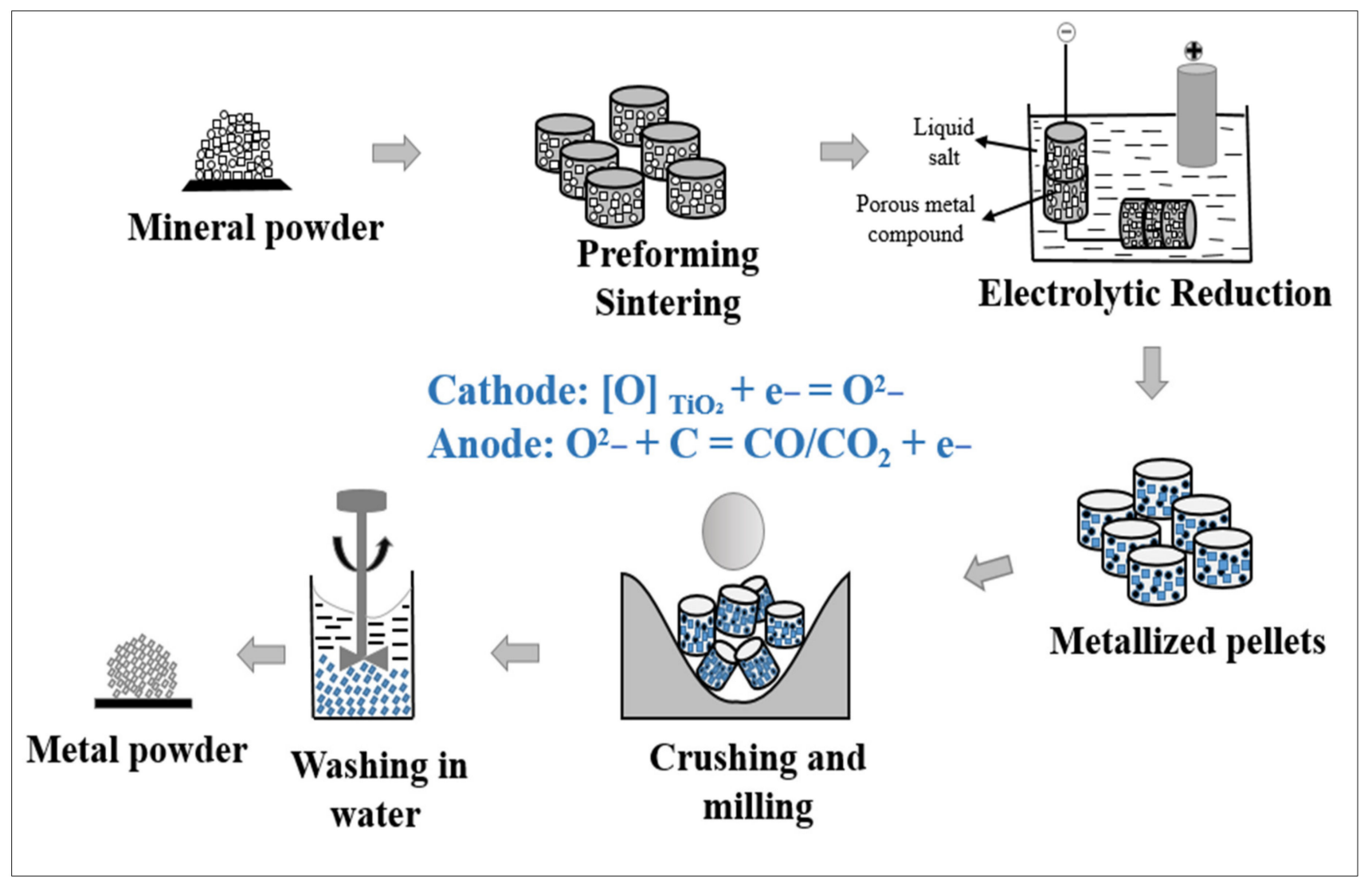

Figure 8. A schematic illustration of the CTF's Cambridge process [81] (Reprinted with permission from Taylor \& Francis, Copyright, (2015)).

\subsubsection{Ono and Suzuki Process}

The (OS) process invented by Ono and Suzuki et al. $[54,82,83]$ is based on a reduction of $\mathrm{TiO}_{2}$ by $\mathrm{Ca}$. Ca is generated by electrolysis of $\mathrm{CaO}$ in molten salt $\mathrm{CaCl}_{2}$. A layer of calcium oxide that inhibits any further reaction was generated by the simple reaction of calcium with titanium dioxide generated (Figure 9); however, the ability of calcium chloride to dissolve significant amounts of calcium oxide may be effective in overcoming this problem [49]. 


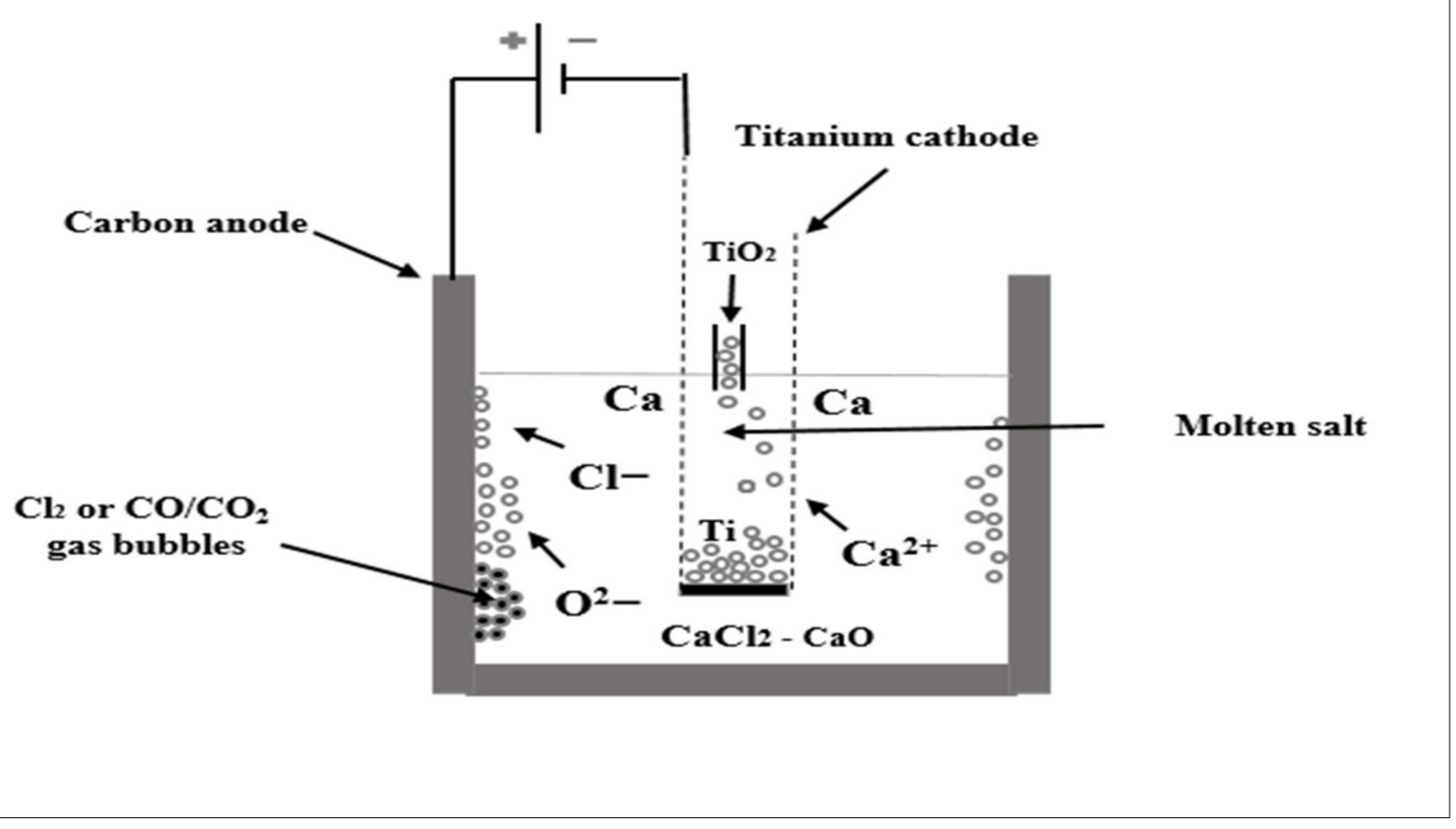

Figure 9. Diagram of the cell used in the OS process [83] (Reprinted with permission from Elsevier, Copyright, (2015)).

\subsubsection{Quebec Iron and Titane (QIT) Process}

The QIT process, patented by François Cardarelli in 2009 [84], is a process for the electrolytic extraction of Ti metal from compounds containing $\mathrm{TiO}_{2}$ in a liquid state. Specifically, this process uses a molten compound containing $\mathrm{TiO}_{2}$ as the cathode on the bottom and a consumable carbon as the anode. A layer of electrolyte, such as molten salts (e.g., $\mathrm{CaF}_{2}$ ) or a solid-state ion conductor is used as the $\mathrm{O}^{-2}$ ion carrier in the middle. The temperature ranges between $1700{ }^{\circ} \mathrm{C}$ and $1900{ }^{\circ} \mathrm{C}$ in this process [76].

There have been several reports on the development of continuous processes based on the same chemistry as the above processes. A new process was presented, which integrates carbochlorination and electrolyzation to elaborate metallic titanium in molten $\mathrm{NaCl}-\mathrm{CaCl}_{2}$ electrolyte [82]. This experiment was made at $577^{\circ} \mathrm{C}$ using some specific precursors like carbon-doped $\mathrm{TiO}_{2}$. Likewise, a pre-treatment is performed to partially reduce $\mathrm{TiO}_{2}$ to titanium sub-oxides with lower valence. The compacted pre-treated mass is electrolyzed at a temperature of $1000{ }^{\circ} \mathrm{C}$ in a molten $\mathrm{CaCl}_{2}$ bath for $1-5 \mathrm{~h}$ [85].

An investigation of the $\mathrm{CaCl}_{2}$ effect on the calcium vapor reduction process of $\mathrm{Ti}_{2} \mathrm{O}_{3}$ has been performed [86]. The compound $\mathrm{CaCl}_{2}$ plays a crucial role in the calciothermic reduction process of $\mathrm{Ti}_{2} \mathrm{O}_{3}$ to prepare porous titanium [86]. Likewise, the generation of a low oxygen Ti powder was carried out by electrolytic reduction of $\mathrm{CaTiO}_{3}$ in a $\mathrm{CaCl}_{2}-\mathrm{CaO}$ melt. By using different sizes of raw oxide particles, the concentration of residual oxygen in the cathode imposes a reduction mechanism using calcium from the cast iron [87]. Another method was introduced for the preparation of titanium metal by reduction of $\mathrm{TiCl}_{4}$ in NaCl-KCl-NaF eutectic melts [88]. A new method for manufacturing porous titanium by in situ calcium vapor reduction of titanium sesquioxide was presented by Yang et al. [89]. By calcium vapor, $\mathrm{Ti}_{2} \mathrm{O}_{3}$ and $\mathrm{CaCl}_{2}$ powders have been reduced. The product was leached with hydrochloric acid and deionized water and the porous structure of $\mathrm{Ti}$ was obtained [89]. Furthermore, $\mathrm{LiCl}-\mathrm{KCl}$ molten salt was used as an electrolyte due to its relatively low melting point to produce metallic titanium. The oxygen content in the titanium crystal is $1200 \mathrm{ppm}$ [90]. 
Commercial $\mathrm{TiO}_{2}$ has been reduced by $\mathrm{Mg}$ in a hydrogen atmosphere [91]. A mandatory deoxygenation process was added to ensure that the purity met standard specifications for titanium. The magnesium reduction and deoxygenation combination process is a holistic approach that produces Ti powders meeting ASTM specifications [91].

Otherwise, for patents published in this sense, Zhu et al. [92] invented a method for the electrowinning of titanium metal from a soluble anode molten salt containing titanium and concerns the technical field of non-ferrous metal metallurgy. In 2009, François Cardarelli [84] also invented a process for the electrowinning of Ti metal from compounds containing a liquid $\mathrm{TiO}_{2}$ (Table 7). This process uses a molten compound containing $\mathrm{TiO}_{2}$ as the cathode in the bottom. The anode can be a consumable carbon, a stable inert anode, or a gas diffusion anode powered by a combustible gas (e.g., $\mathrm{H}_{2}, \mathrm{CO}$, etc.). The temperature reaches $1700{ }^{\circ} \mathrm{C}$ to $1900{ }^{\circ} \mathrm{C}$ for this process [76].

As shown above, there are many methods and newly developed technologies to produce titanium powder. Kroll process the most utilized one can produce titanium with less oxygen content and metallic impurities, but its productivity is still very low, magnesium as a reductant has a high cost compared to other metals such as calcium and aluminum, and it is a labor-intensive batch process. Furthermore, the hunter process produces titanium powder purer than Kroll's powder but uses an expensive sodium reductant and heterogeneous exothermic reactions. For other processes, they present advantages at the production level but they are still at the laboratory scale and require more time to be developed in the industry. It is possible to develop a method to directly reduce oxides to efficiently produce Ti with low oxygen amount in the next few years. In principle, the production of high purity metallic Ti by direct reduction of Ti precursors is possible; hence, a method that relies on the melting of these oxides and is based on the principles of the Kroll process should be developed as a new approach to establish a low-cost Ti reduction process.

On the other hand, new technologies are developed as an alternative to the Kroll process. The electrochemical road is the best choice for many industries. The FCC Cambridge provides a product with almost 0.3 mass $\%$ oxygen, and it is a semi-continuous operation. However, this method exhibits many drawbacks: low current efficiency $(20-40 \%)$, slow oxygen diffusion, difficult separation of metal/salt, and is costly for the $\mathrm{TiO}_{2}$ pellet feed. On the other hand, the OS process can produce titanium directly from $\mathrm{TiO}_{2}$ reduction in molten salt, but it still has some problem contamination because of the presence of carbon. Furthermore, many electrochemical procedures have been performed recently. They dictate a good enhancement in the cost and production issues, but they are difficult to scale up for the difficulty in facilitating a homogeneous reaction. 
Table 7. Advantages and disadvantages of some patents in titanium production based on electrochemical technics.

\begin{tabular}{|c|c|c|c|c|}
\hline Publication $\mathrm{N}^{\circ}$ & Title & Advantages & Disadvantages & Reference \\
\hline $\begin{array}{c}\text { US 10, } 081,874 \text { B2 } \\
(2018)\end{array}$ & $\begin{array}{l}\text { Method for electrowinning titanium } \\
\text { from titanium-containing soluble anode } \\
\text { molten salt }\end{array}$ & $\begin{array}{l}\text { This invention has the advantages of a short process flow, high carbothermal } \\
\text { reduction efficiency, fewer intermediate products, direct availability of } \\
\text { high-purity titanium, low purity requirements for anodic raw materials, low } \\
\text { energy consumption, environmental friendliness, etc }\end{array}$ & $\begin{array}{ll}\text { - } & \text { Use of toxic products. } \\
\text { - } & \text { High temperatures }\end{array}$ & [92] \\
\hline $\begin{array}{l}\text { US } 7,790,014 \text { B2 } \\
\quad(2010)\end{array}$ & $\begin{array}{l}\text { Removal of substances from metal and } \\
\text { semi-metal compounds }\end{array}$ & $\begin{array}{l}\text { - } \mathrm{CaCl}_{2} \text { is used as a salt (can dissolve and transport oxygen ion), cheaper and } \\
\text { less toxic than } \mathrm{MgCl}_{2} \\
\text { - } \quad \text { One-step process that does not use } \mathrm{Mg} \text { as a reducing agent } \\
\text { Can also be used for the direct production of alloys, which could lead to } \\
\text { savings in other ways }\end{array}$ & $\begin{array}{ll}- & \text { Low yield. } \\
\text { - } & \text { Possibility of incomplete or partial } \\
& \text { reduction of } \mathrm{TiO}_{2}\end{array}$ & [93] \\
\hline $\begin{array}{l}\text { US } 7,504,017 \text { B2 } \\
\text { (2009) }\end{array}$ & $\begin{array}{l}\text { Method for electrowinning of titanium } \\
\text { metal or alloy from titanium oxide } \\
\text { containing compound in the liquid state }\end{array}$ & $\begin{array}{l}\text { - } \quad \begin{array}{l}\text { Electrochemical deoxidation is a one-step process } \\
\text { - }\end{array} \text { Cheaper raw material. } \\
\text { Use of molten titanium oxide slag as cathode material, preferably as such, } \\
\text { - } \quad \text { Opithout prior treatment and without the introduction of additives } \\
\text { of the titanium oxide slysis at a temperature above the liquidus temperature } \\
\text { allowing the electrodeposited titanium droplets to be rapidly collected by } \\
\text { gravity } \\
\text { Providing a molten material for use as a molten cathode material }\end{array}$ & $\begin{array}{ll}\text { - } & \text { High reaction temperatures } \\
\text { - } & \text { High temperature furnace with } \\
\text { consumable carbon anodes } \\
\text { - } \quad \text { Exhaust of } \mathrm{CO}_{2} \text { gas }\end{array}$ & [84] \\
\hline $\begin{array}{l}\text { US 7.410,562 B2 } \\
\text { (2011) }\end{array}$ & $\begin{array}{l}\text { Thermal and electrochemical process for } \\
\text { metal production }\end{array}$ & 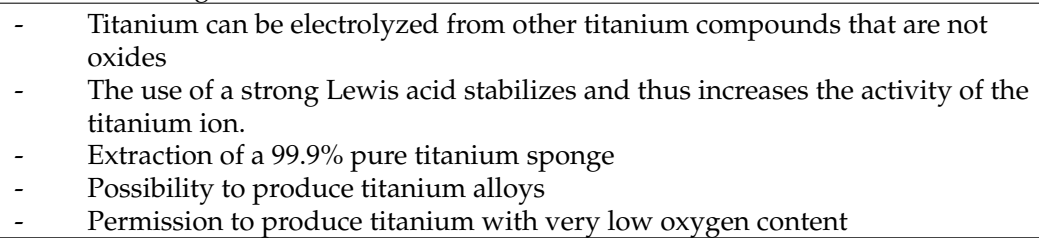 & $\begin{array}{ll}\text { - } & \text { High temperatures and pressures } \\
\text { - } & \text { Problem of oxidation. } \\
\text { - } & \text { Very energy consumable }\end{array}$ & [94] \\
\hline $\begin{array}{c}\text { EP } 2322693 \text { B1 } \\
\text { (2004) }\end{array}$ & $\begin{array}{l}\text { Electrochemical process for titanium } \\
\text { production }\end{array}$ & $\begin{array}{ll}- & \text { Use of cheaper and less toxic molten salts } \\
- & \text { Reduction of oxygen content }(<400 \mathrm{ppm}) \\
- & \text { Use of cheaper and non-consumable graphite cathodes }\end{array}$ & $\begin{array}{ll}\text { - } & \text { High temperatures } \\
\text { - } & \text { Difficulty controlling contamination. }\end{array}$ & [95] \\
\hline $\begin{array}{l}\text { US } 2007 / 0029208 \mathrm{~A} 1 \\
(2008)\end{array}$ & $\begin{array}{l}\text { Thermal and electrochemical process for } \\
\text { metal production }\end{array}$ & $\begin{array}{ll}- & \text { Extraction of the titanium sponge with a purity of } 99.9 \% \\
- & \text { Possibility to produce titanium alloys. } \\
- & \text { Production of titanium with very low oxygen content }\end{array}$ & $\begin{array}{ll}- & \text { High temperatures and pressures } \\
- & \text { Oxidation problem } \\
- & \text { Very energy consumable } \\
\end{array}$ & [96] \\
\hline
\end{tabular}




\section{Conclusions}

Titanium has remained an essential metal because of its wide use in different fields. Its demand in the industry has prompted unprecedented technical progress. Natural ilmenite is the most abundant titanium-bearing mineral in the earth's crust. The mineral ilmenite has been significantly grown since his discovery. Nowadays, it is the most crucial ore of titanium. The presented review shows the presence of enormous techniques for manufacturing titanium powder and titanium metal. Many of these processes are at various stages of development. The incentive for the development of new processes is often firmly rooted in the ambition to achieve a low-cost alternative to the Kroll process for the production of primary Ti metal. Marketed chloride-based thermochemical processes, such as the Kroll and Hunter processes, are batch operations and require high-quality natural rutile or improved synthetic slag, such as feeding and using cost-sensitive chlorination and thermochlorination steps. Many improvements have been made to thermochemical processes, but they offer few opportunities for cost reduction beyond current technology. Several development methods have generated considerable interest and scale-up efforts, including the Armstrong process and the FFC Cambridge process. The former is an example of using a continuous process for the reduction of $\mathrm{TiCl}_{4}$ with $\mathrm{Na}$ or $\mathrm{Mg}$ while the latter is an example of the various electrochemical methods that convert $\mathrm{TiO}_{2}$ into $\mathrm{Ti}$ metal in molten salt. A recently developed method, named the HAMR process, is based on destabilizing the Ti-O system by using hydrogen as a temporary alloying element during the magnesium thermal reduction of $\mathrm{TiO}_{2}$. However, compared with the Kroll, these producers are expanding their production to meet the unprecedented demand for titanium. Overall, it is expected that it will take several years before any new process will be in commercial production and compete with the Kroll process.

Author Contributions: Conceptualization, M.E.K. and G.S.; formal analysis, M.E.K.; funding acquisition, G.S.; investigation, M.E.K.; methodology, M.E.K., G.S. and O.D.; resources, G.S.; supervision, G.S.; validation, M.E.K.; writing—original draft preparation, M.E.K.; writing—review and editing, G.S. and O.D. All authors have read and agreed to the published version of the manuscript.

Funding: This study was funded by NSERC (Natural Sciences and Engineering Research Council of Canada) discovery grant (RGPIN-2018-06128) and Metchib company-Quebec, Canada.

Acknowledgments: Metchib Company supported this research. We thank Metchib Company in Canada for providing rock samples and supporting us.

Conflicts of Interest: The authors declare no conflict of interest.

\section{References}

1. Sibum, H. Titanium and titanium alloys-From raw material to semi-finished products. Adv. Eng. Mater. 2003, 5, 393-398. [CrossRef]

2. Leyens, C.; Peters, M. Titanium and Titanium Alloys: Fundamentals and Applications; John Wiley \& Sons: Hoboken, NJ, USA, 2003.

3. Cui, C.; Hu, B.; Zhao, L.; Liu, S. Titanium alloy production technology, market prospects and industry development. Mater. Des. 2011, 32, 1684-1691. [CrossRef]

4. Mutava, T.D. Characterisation of a Titanium Precursor Salt and Study of Some of the Treatment Steps Used for the Extraction Process. Ph.D. Thesis, University of the Witwatersrand, Johannesburg, South Africa, 2009.

5. Jackson, M.; Dring, K. A review of advances in processing and metallurgy of titanium alloys. Mater. Sci. Technol. 2006, 22, 881-887. [CrossRef]

6. Force, E.R. Geology of Titanium-Mineral Deposits; Geological Society of America: Boulder, CO, USA, 1991 ; Volume 259.

7. U.S. Geological Survey. Mineral Commodity Summaries 2021; U.S. Geological Survey: Reston, VA, USA, 2021; 200p.

8. Force, E.R. Geology and Resources of Titanium; Geological Society of America: Boulder, CO, USA, 1976.

9. Van Gosen, B.S.; Fey, D.L.; Shah, A.K.; Verplanck, P.L.; Hoefen, T.M. Deposit Model for Heavy-Mineral Sands in Coastal Environments: Chapter L in Mineral Deposit Models for Resource Assessment; US Geological Survey: Reston, VI, USA, 2014.

10. Fadeel, B. Handbook of Safety Assessment of Nanomaterials: From Toxicological Testing to Personalized Medicine; Pan Stanford; CRC Press: Boca Raton, FL, USA, 2014.

11. Fang, Z.Z.; Paramore, J.D.; Sun, P.; Chandran, K.R.; Zhang, Y.; Xia, Y.; Free, M. Powder metallurgy of titanium-Past, present, and future. Int. Mater. Rev. 2018, 63, 407-459. [CrossRef] 
12. Ma, M.; Wang, D.; Wang, W.; Hu, X.; Jin, X.; Chen, G.Z. Extraction of titanium from different titania precursors by the FFC Cambridge process. J. Alloys Compd. 2006, 420, 37-45. [CrossRef]

13. Kroll, W. The production of ductile titanium. Trans. Electrochem. Soc. 1940, 78, 35-47. [CrossRef]

14. Berthaud, M. Étude du Comportement de L'alliage de Titane Ti6242S à Haute Température sous Atmosphères Complexes: Applications Aéronautiques. Ph.D. Thesis, Université Bourgogne Franche-Comté, Besançon, France, 2018.

15. Samal, S. Thermal Plasma Processing of Ilmenite; Springer: Berlin/Heildelberg, Germany, 2017.

16. Froes, F. Titanium: Physical Metallurgy, Processing, and Applications; ASM International: Novelty, OH, USA, 2015.

17. Fang, Z.Z.; Lefler, H.D.; Froes, F.H.; Zhang, Y. Introduction to the development of processes for primary Ti metal production. In Extractive Metallurgy of Titanium; Elsevier: Amsterdam, The Netherlands, 2020; pp. 1-10.

18. Biehl, V.; Wack, T.; Winter, S.; Seyfert, U.T.; Breme, J. Evaluation of the haemocompatibility of titanium based biomaterials. Biomol. Eng. 2002, 19, 97-101. [CrossRef]

19. Bessinger, D.; Geldenhuis, J.M.A.; Pistorius, P.C.; Mulaba, A.; Hearne, G. The decrepitation of solidified high titania slags. J. Non Cryst. Solids 2001, 282, 132-142. [CrossRef]

20. Nagesh, C.R.; Ramachandran, C.; Subramanyam, R. Methods of titanium sponge production. Trans. Indian Inst. Met. 2008, 61, 341-348. [CrossRef]

21. Vilakazi, A.Q. Hydrometallurgical Beneficiation of Ilmenite. Ph.D. Thesis, University of the Free State, Bloemfontein, South Africa, 2017.

22. Wilson, N.C.; Muscat, J.; Mkhonto, D.; Ngoepe, P.E.; Harrison, N.M. Structure and properties of ilmenite from first principles. Phys. Rev. B 2005, 71, 075202. [CrossRef]

23. Charlier, B.; Namur, O.; Bolle, O.; Latypov, R.; Duchesne, J.C. Fe-Ti-V-P ore deposits associated with Proterozoic massif-type anorthosites and related rocks. Earth-Sci. Rev. 2015, 141, 56-81. [CrossRef]

24. Korneliussen, A.; McENROE, S.A.; Nilsson, L.P.; Schiellerup, H.; Gautneb, H.; Meyer, G.B.; Storseth, L.R. An overview of titanium deposits in Norway. Norges Geologiske Undersokelse 2000, 436, 27-38.

25. Froes, F. Titanium powder metallurgy: A review-part 1. Adv. Mater. Process. 2012, 170, 16-22.

26. McCracken, C.G.; Motchenbacher, C.; Barbis, D.P. Review of titanium powder production methods. Int. J. Powder Metall. 2010, 46, 19-25.

27. Hunter, M. Metallic titanium. J. Am. Chem. Soc. 1910, 32, 330-336. [CrossRef]

28. Florkiewicz, W.; Malina, D.; Tyliszczak, B.; Sobczak-Kupiec, A. Manufacturing of titanium and its alloys. In Sustainable Production: Novel Trends in Energy, Environment and Material Systems; Springer: Berlin, Heidelberg, 2020; pp. 61-74.

29. Hartman, A.D.; Gerdemann, S.J.; Hansen, J.S. Producing lower-cost titanium for automotive applications. JOM 1998, 50, 16-19. [CrossRef]

30. Kohli, R. Production of Titanium from Ilmenite: A Review; Lawrence Berkeley Lab.: Berkeley, CA, USA, 1981.

31. Gambogi, J.; Gerdemann, S. Titanium metal: Extraction to application. In Review of Extraction, Processing, Properties E Applications of Reactive Metals; John Wiley \& Sons: Hoboken, NJ, USA, 1999; pp. 175-210.

32. Agripa, H.; Botef, I. Modern production methods for titanium alloys: A review. In Titanium Alloys-Novel Aspects of Their Processing; IntechOpen: London, UK, 2019.

33. Kraft, E. Summary of Emerging Titanium Cost Reduction Technologies; EHK Technologies: Burlington, WA, USA, 2004.

34. Crowley, G. How to extract low-cost titanium. Adv. Mater. Process. 2003, 161, 25-27.

35. Chen, W.; Yamamoto, Y.; Peter, W.H. Investigation of pressing and sintering processes of CP-Ti powder made by Armstrong Process. In Key Engineering Materials; Trans Tech Publications: Stafa-Zurich, Switzerland, 2010.

36. Araci, K.; Mangabhai, D.; Akhtar, K. Production of titanium by the Armstrong Process ${ }^{\circledR}$. In Titanium Powder Metallurgy; Elsevier: Amsterdam, The Netherlands, 2015; pp. 149-162.

37. Brooks, G.; Cooksey, M.; Wellwood, G.; Goodes, C. Challenges in light metals production. Miner. Process. Extr. Metall. 2007, 116, 25-33. [CrossRef]

38. Doblin, C.; Chryss, A.; Monch, A. Titanium powder from the TiRO ${ }^{\mathrm{TM}}$ process. In Key Engineering Materials; Trans Tech Publications: Stafa-Zurich, Switzerland, 2012.

39. Van Vuuren, D.S. Direct titanium powder production by metallothermic processes. In Titanium Powder Metallurgy; Elsevier: Amsterdam, The Netherlands, 2015; pp. 69-93.

40. Hansen, D.A.; Gerdemann, S.J. Producing titanium powder by continuous vapor-phase reduction. JOM 1998, 50, 56-58. [CrossRef]

41. Van Vuuren, D.; Oosthuizen, S.; Heydenrych, M.D. Titanium production via metallothermic reduction of TiCl4in molten salt: Problems and products. J. S. Afr. Inst. Min. Metall. 2011, 111, 141-147.

42. Mo, W.; Deng, G.; Luo, F. Titanium Metallurgy; Metallurgical Industry Press: Beijing, China, 1998.

43. Mishra, B.; Kipouros, G.J. Titanium Extraction and Processing; The Minerals, Metals \& Materials Society: Warrendale, PA, USA, 1997.

44. Borok, B. Obtaining powders of alloys and steels by a complex reduction of oxide mixtures by CaH 2 . Trans. Cent. Res. Inst. Ferr. Met. 1965, 43, 69-80.

45. Froes, F. The production of low-cost titanium powders. JOM J. Miner. Met. Mater. Soc. 1998, 50, 41-43. [CrossRef]

46. Zhang, Y.; Fang, Z.Z.; Sun, P.; Zheng, S.; Xia, Y.; Free, M. A Perspective on thermochemical and electrochemical processes for titanium metal production. JOM 2017, 69, 1861-1868. [CrossRef] 
47. Park, I.; Abiko, T.; Okabe, T.H. Production of titanium powder directly from $\mathrm{TiO}_{2}$ in $\mathrm{CaCl}_{2}$ through an electronically mediated reaction (EMR). J. Phys. Chem. Solids 2005, 66, 410-413. [CrossRef]

48. Okabe, T.H.; Oda, T.; Mitsuda, Y. Titanium powder production by preform reduction process (PRP). J. Alloys Compd. 2004, 364, 156-163. [CrossRef]

49. Fray, D. Novel methods for the production of titanium. Int. Mater. Rev. 2008, 53, 317-325. [CrossRef]

50. Zhang, Y.; Fang, Z.Z.; Xia, Y.; Huang, Z.; Lefler, H.; Zhang, T.; Guo, J. A novel chemical pathway for energy efficient production of Ti metal from upgraded titanium slag. Chem. Eng. J. 2016, 286, 517-527. [CrossRef]

51. Fang, Z.Z.; Zhang, Y.; Xia, Y.; Sun, P. Methods of Producing a Titanium Product. U.S. Patent 2016/0108497 A1, 23 June 2016.

52. Froes, F.; Eylon, D. Powder metallurgy of titanium alloys. Int. Mater. Rev. 1990, 35, 162-184. [CrossRef]

53. Alexander, P.P. Production of Titanium Hydride. U.S. Patent 2,427,338, 16 September 1947.

54. Suzuki, R.O.; Ono, K.; Teranuma, K. Calciothermic reduction of titanium oxide and in-situ electrolysis in $\mathrm{molten}^{\mathrm{CaCl}} \mathrm{C}_{2} \cdot \mathrm{Metall}$ Mater. Trans. B 2003, 34, 287-295. [CrossRef]

55. Abiko, T.; Park, I.; Okabe, T.H. Reduction of titanium oxide in molten salt medium. In Proceedings of the 10th World Conference on Titanium, Ti-2003, Hamburg, Germany, 13-18 July 2003.

56. Won, C.; Nersisyan, H.; Won, H. Titanium powder prepared by a rapid exothermic reaction. Chem. Eng. J. 2010, 157, 270-275. [CrossRef]

57. Nersisyan, $\mathrm{H}$. ; Lee, J.; Won, $\mathrm{C}$. Combustion of $\mathrm{TiO}_{2}-\mathrm{Mg}$ and $\mathrm{TiO}_{2}-\mathrm{Mg}-\mathrm{C}$ systems in the presence of $\mathrm{NaCl}$ to synthesize nanocrystalline Ti and TiC powders. Mater. Res. Bull. 2003, 38, 1135-1146. [CrossRef]

58. Zhang, Y.; Fang, Z.Z.; Sun, P.; Zhang, T.; Xia, Y.; Zhou, C.; Huang, Z. Thermodynamic destabilization of Ti-O solid solution by $\mathrm{H}_{2}$ and deoxygenation of Ti using Mg. J. Am. Chem. Soc. 2016, 138, 6916-6919. [CrossRef] [PubMed]

59. Lu, X.; Ono, T.; Takeda, O.; Zhu, H. Production of fine titanium powder from titanium sponge by the shuttle of the disproportionation reaction in molten $\mathrm{NaCl}-\mathrm{KCl}$. Mater. Trans. 2019, 60, 405-410. [CrossRef]

60. Ardani, M.R.; Al Janabi, A.S.M.; Udayakumar, S.; Hamid, S.A.R.S.A.; Mohamed, A.R.; Lee, H.L.; Ibrahim, I. Reduction of TiCl 4 to $\mathrm{TiH}_{2}$ with $\mathrm{CaH}_{2}$ in presence of Ni powder. In Rare Metal Technology 2019; Springer: Berlin/Heidelberg, Germany, 2019; pp. 131-144.

61. Lei, X.; Xu, B.; Yang, G.; Shi, T.; Liu, D.; Yang, B. Direct calciothermic reduction of porous calcium titanate to porous titanium. Mater. Sci. Eng. C 2018, 91, 125-134. [CrossRef]

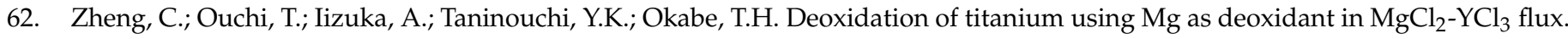
Metall. Mater. Trans. B 2019, 50, 622-631. [CrossRef]

63. Spreitzer, D.; Schenk, J. Iron ore reduction by hydrogen using a laboratory scale fluidized bed reactor: Kinetic investigationExperimental setup and method for determination. Metall. Mater. Trans. B 2019, 50, 2471-2484. [CrossRef]

64. Bolivar, R.; Friedrich, B. Magnesiothermic reduction from titanium dioxide to produce titanium powder. J. Sustain. Metall. 2019, 5, 219-229. [CrossRef]

65. Mojisola, T.; Ramakokovhu, M.M.; Raethel, J.; Olubambi, P.A.; Matizamhuka, W.R. In-situ synthesis and characterization of $\mathrm{Fe}-\mathrm{TiC}$ based cermet produced from enhanced carbothermally reduced ilmenite. Int. J. Refract. Met. Hard Mater. 2019, 78, 92-99. [CrossRef]

66. Chae, J.; Oh, J.M.; Yoo, S.; Lim, J.W. Eco-friendly pretreatment of titanium turning scraps and subsequent preparation of ferro-titanium ingots. Korean J. Met. Mater. 2019, 57, 569-574. [CrossRef]

67. Ri, V.; Nersisyan, H.; Kwon, S.C.; Lee, J.H.; Suh, H.; Kim, J.G. A thermochemical and experimental study for the conversion of ilmenite sand into fine powders of titanium compounds. Mater. Chem. Phys. 2019, 221, 1-10. [CrossRef]

68. Gao, Z.; Cheng, G.; Yang, H.; Xue, X.; Ri, J. Preparation of ferrotitanium using ilmenite with different reduction degrees. Metals 2019, 9, 962. [CrossRef]

69. Zhang, G.; Gou, H.; Wu, K.; Chou, K. Carbothermic reduction of Panzhihua ilmenite in vacuum. Vacuum 2017, 143, 199-208. [CrossRef]

70. Kim, D.H.; Kim, T.S.; Heo, J.H.; Park, H.S.; Park, J.H. Influence of temperature on reaction mechanism of ilmenite ore smelting for titanium production. Metall. Mater. Trans. B 2019, 50, 1830-1840. [CrossRef]

71. Mu, H.; Mu, T.; Zhao, S.; Zhu, F.; Deng, B.; Peng, W.; Yan, B. Method of Producing Titanium Metal With Titanium-Containing Material. U.S. Patent 9,963,796, 8 May 2018.

72. Fisher, R.L. Deoxidation of Titanium and Similar Metals Using a Deoxidant in a Molten Metal Carrier. U.S. Patent 4,923,531, 8 May 1990.

73. Cox, J.R.; DeALWIS, C.L.; Kohler, B.A.; Lewis, M.G. System and Method for Extraction and Refining of Titanium. U.S. Patent 10,066,308, 4 September 2018.

74. Moxson, V.S.; Duz, V.A.; Klevtsov, A.G.; Sukhoplyuyev, V.D.; Sopka, M.D.; Shuvalov, Y.V.; Matviychuk, M. Method of Manufacturing Pure Titanium Hydride Powder and Alloyed Titanium Hydride Powders by Combined Hydrogen-Magnesium Reduction of Metal Halides. U.S. Patent 9,067,264, 30 June 2015.

75. Klevtsov, A.; Nikishin, A.; Shuvalov, J.; Moxson, V.; Duz, V. Continuous and Semi-Continuous Process of Manufacturing Titanium Hydride Using Titanium Chlorides of Different Valency. U.S. Patent 8,388,727, 5 March 2013.

76. Shimotori, K.; Ochi, Y.; Ishihara, H.; Umeki, T.; Ishigami, T. Highly Pure Titanium. U.S. Patent RE34,598, 3 May 1994. 
77. Kasparov, S.A.; Klevtsov, A.G.; Cheprasov, A.I.; Moxson, V.S.; Duz, V.A. Semi-Continuous Magnesium-Hydrogen Reduction Process for Manufacturing of Hydrogenated, Purified Titanium Powder. U.S. Patent 8,007,562, 30 August 2011.

78. Fang, Z.Z.; Zhang, Y.; Xia, Y.; Sun, P. Methods of Producing a Titanium Product. U.S. Patent 10,689,730, 23 June 2020.

79. Hanusiak, W.M.; McBride, D.R. Titanium Powder Production Apparatus and Method. U.S. Patent 10,583,492, 10 March 2020.

80. Chen, G.Z.; Fray, D.J.; Farthing, T.W. Direct electrochemical reduction of titanium dioxide to titanium in molten calcium chloride. Nature 2000, 407, 361. [CrossRef]

81. Chen, G.Z. The FFC Cambridge process and its relevance to valorisation of ilmenite and titanium-rich slag. Miner. Process. Extr. Metall. 2015, 124, 96-105. [CrossRef]

82. Zhao, K.; Wang, Y.; Gao, F. Electrochemical extraction of titanium from carbon-doped titanium dioxide precursors by electrolysis in chloride molten salt. Ionics 2019, 12, 6107-6114. [CrossRef]

83. Furuta, T.; Nishino, K.; Hwang, J.; Yamada, A.; Ito, K.; Osawa, S.; Kuramoto, S.; Suzuki, N.; Chen, R.; Saito, T. Development of multi functional titanium alloy, "Gum Metal”. In Ti-2003 Science and Technology; Lütjering, G., Albrecht, J., Eds.; Wiley-VCH: Weinheim, Germany, 2004.

84. Cardarelli, F. Method for Electrowinning of Titanium Metal or Alloy from Titanium Oxide Containing Compound in the Liquid State. U.S. Patent 7,504,017, 17 March 2009.

85. Mohanty, J.; Behera, P.K. Use of pre-treated $\mathrm{TiO}_{2}$ as cathode material to produce Ti metal through molten salt electrolysis. Trans. Indian Inst. Met. 2019, 72, 859-865. [CrossRef]

86. Yang, G.; Xu, B.; Wan, H.; Wang, F.; Yang, B.; Wang, Z. Effect of $\mathrm{CaCl}_{2}$ on microstructure of calciothermic reduction products of $\mathrm{Ti}_{2} \mathrm{O}_{3}$ to prepare porous titanium. Metals 2018, 8, 698. [CrossRef]

87. Noguchi, H.; Natsui, S.; Kikuchi, T.; Suzuki, R.O. Reduction of $\mathrm{CaTiO}_{3}$ by electrolysis in the molten salt CaCl ${ }_{2}-\mathrm{CaO}_{\text {. Electrochemistry }}$ 2018, 86, 82-87. [CrossRef]

88. Zhu, F.; Qiu, K.; Sun, Z. Preparation of titanium from $\mathrm{TiCl}_{4}$ in a molten fluoride-chloride salt. Electrochemistry 2017, 85, 715-720. [CrossRef]

89. Yang, G.; Xu, B.; Lei, X.; Wan, H.; Yang, B.; Liu, D.; Wang, Z. Preparation of porous titanium by direct in-situ reduction of titanium sesquioxide. Vacuum 2018, 157, 453-457. [CrossRef]

90. Li, C.; Song, J.; Li, S.; Li, X.; Shu, Y.; He, J. An investigation on electrodeposition of titanium in molten LiCl-KCl. In Materials Processing Fundamentals 2019; Springer: Berlin/Heidelberg, Germany, 2019; pp. 193-202.

91. Xia, Y.; Fang, Z.Z.; Zhang, Y.; Lefler, H.; Zhang, T.; Sun, P.; Huang, Z. Hydrogen assisted magnesiothermic reduction (HAMR) of commercial $\mathrm{TiO}_{2}$ to produce titanium powder with controlled morphology and particle size. Mater. Trans. 2017, 58, 355-360. [CrossRef]

92. Zhu, H.; Wang, Q.; Jiao, S. Method for Electrowinning Titanium from Titanium-Containing Soluble Anode Molten Salt. U.S. Patent 10,081,874, 25 September 2018.

93. Fray, D.J.; Farthing, T.W.; Chen, Z. Removal of Substances from Metal and Semi-Metal Compounds. U.S. Patent 7,790,014, 7 September 2010.

94. Withers, J.C.; Loutfy, R.O. Thermal and Electrochemical Process for Metal Production. U.S. Patent 7,985,326, 26 July 2011.

95. Withers, J.C.; Loutfy, R.O. Electrochemical Process for Titanium Production. U.S. Patent EP 2322693 B1, 18 August 2004.

96. Withers, J.C.; Loutfy, R.O. Thermal and Electrochemical Process for Metal Production. U.S. Patent 2007/0029208A1, 8 February 2008. 